\title{
Review of Electrochemical DNA Biosensors for Detecting Food Borne Pathogens
}

\author{
Qiaoyun $\mathrm{Wu}^{1,+}$, Yunzhe Zhang ${ }^{1,+}$, Qian Yang ${ }^{2}$, Ning Yuan ${ }^{2}$ and Wei Zhang ${ }^{1,2, *}$ \\ 1 College of Food Science and Technology, Hebei Agricultural University, Baoding 071001, China; \\ maxiaoyan@hebau.edu.cn (Q.W.); zhangyunzhe@hebau.edu.cn (Y.Z.) \\ 2 College of Science and Technology, Hebei Agricultural University, Cangzhou 061100, China; \\ yangqian@hebau.edu.cn (Q.Y.); yuanning@hebau.edu.cn (N.Y.) \\ * Correspondence: zhangwei@hebau.edu.cn \\ + These authors contributed equally to this work.
}

Received: 26 September 2019; Accepted: 8 November 2019; Published: 12 November 2019

\begin{abstract}
The vital importance of rapid and accurate detection of food borne pathogens has driven the development of biosensor to prevent food borne illness outbreaks. Electrochemical DNA biosensors offer such merits as rapid response, high sensitivity, low cost, and ease of use. This review covers the following three aspects: food borne pathogens and conventional detection methods, the design and fabrication of electrochemical DNA biosensors and several techniques for improving sensitivity of biosensors. We highlight the main bioreceptors and immobilizing methods on sensing interface, electrochemical techniques, electrochemical indicators, nanotechnology, and nucleic acid-based amplification. Finally, in view of the existing shortcomings of electrochemical DNA biosensors in the field of food borne pathogen detection, we also predict and prospect future research focuses from the following five aspects: specific bioreceptors (improving specificity), nanomaterials (enhancing sensitivity), microfluidic chip technology (realizing automate operation), paper-based biosensors (reducing detection cost), and smartphones or other mobile devices (simplifying signal reading devices).
\end{abstract}

Keywords: food borne pathogens detection; electrochemical DNA biosensors; bioreceptors; nanomaterials; DNA amplification

\section{Introduction}

Due to the widespread outbreak of food borne epidemics in both developed and developing countries, people are paying increasing attention to public health issue. Studies have shown that the main cause of food safety problems is food borne pathogens including E. coli O157:H7, Staphylococcus aureus, Salmonella, Listeria monocytogenes, etc. [1-4]. Food products and their raw materials are dominant transmitting agent of more than 250 known diseases [5,6]. Table 1 summarizes the relevant pathogens spread through food matrix, their main sources, virulence factors, as well as the associated epidemics. Owing to the abundance of various nutrients, raw materials are generally preferred hosts for microorganisms to grow. Although heating process can kill most of the potential bacteria in food, the emergence of ready-to-eat food in recent years increases the probability of exposure to pathogenic contamination [1]. Food products are highly susceptible to microbial contamination during processing, packaging, distribution, storage, and other stages [2]. Thus, in a modern industrial environment, the control of food processing and real-time monitoring of food borne pathogens are of paramount importance to ensure consumers' safety. 
Table 1. Common food-borne pathogens.

\begin{tabular}{|c|c|c|c|c|c|}
\hline Pathogens & Gram & Virulence Factors & Epidemics & Food Source & Refs. \\
\hline Salmonella & - & Enterotoxin & $\begin{array}{l}\text { Typhoid fever, } \\
\text { paratyphoid fever, } \\
\text { gastroenteritis, and } \\
\text { septicemia }\end{array}$ & $\begin{array}{l}\text { Egg, raw milk and their } \\
\text { products, commercial } \\
\text { cold food dishes, raw } \\
\text { poultry and meat }\end{array}$ & [3-7] \\
\hline E. coli $\mathrm{O} 157: \mathrm{H7}$ & - & $\begin{array}{l}\text { Endotoxin, exotoxin, } \\
\text { capsule, and adhesin. }\end{array}$ & $\begin{array}{l}\text { Acute gastroenteritis and } \\
\text { acute dysentery }\end{array}$ & $\begin{array}{l}\text { Meat, fruits, vegetables, } \\
\text { commercial cold food } \\
\text { dishes, ready-to-eat food, } \\
\text { drinking water }\end{array}$ & {$[7-15]$} \\
\hline $\begin{array}{l}\text { Listeria } \\
\text { monocytogenes }\end{array}$ & + & $\begin{array}{l}\text { Endogenous } \\
\text { hormone, } \\
\text { phagosome, and } \\
\text { surface protein }\end{array}$ & Listeriosis & $\begin{array}{l}\text { Frozen food, cheese, } \\
\text { milk, meat products, ice, } \\
\text { vegetable salad, } \\
\text { ready-to-eat food, } \\
\text { commercial cold food } \\
\text { dishes }\end{array}$ & {$[7,16-23]$} \\
\hline $\begin{array}{l}\text { Staphylococcus } \\
\text { aureus }\end{array}$ & + & $\begin{array}{l}\text { Hemolytic toxin, } \\
\text { leukocidin, } \\
\text { enterotoxin, plasma } \\
\text { coagulase, and } \\
\text { deoxyribonuclease }\end{array}$ & $\begin{array}{l}\text { Suppurative infection, } \\
\text { pneumonia, } \\
\text { pseudomembranous } \\
\text { colitis, pericarditis, sepsis, } \\
\text { septicemia }\end{array}$ & $\begin{array}{l}\text { Milk, meat, eggs, fish } \\
\text { and their products, } \\
\text { commercial cold food } \\
\text { dishes }\end{array}$ & {$[7,24-26]$} \\
\hline Shigella & - & $\begin{array}{l}\text { Endotoxin and } \\
\text { exotoxin }\end{array}$ & Bacterial dysentery & $\begin{array}{l}\text { Cooked food and raw } \\
\text { material }\end{array}$ & [27-29] \\
\hline Cronobacter & - & $\begin{array}{l}\text { Enterotoxin, and } \\
\text { adhesion factor }\end{array}$ & $\begin{array}{l}\text { Necrotizing colitis, } \\
\text { neonatal meningitis, and } \\
\text { bacteremia }\end{array}$ & $\begin{array}{l}\text { Powdered infant } \\
\text { formula and milk } \\
\text { powder }\end{array}$ & [30-33] \\
\hline $\begin{array}{c}\text { Vibrio } \\
\text { parahemolyticus }\end{array}$ & - & $\begin{array}{l}\text { Hemolysin and } \\
\text { urease }\end{array}$ & $\begin{array}{l}\text { Food poisoning, and acute } \\
\text { diarrhea }\end{array}$ & $\begin{array}{l}\text { Seafood such as fish, } \\
\text { shrimp, crab, shellfish, } \\
\text { and seaweed }\end{array}$ & [34-36] \\
\hline Proteus & - & $\begin{array}{l}\text { Endotoxin, and } \\
\text { heat-resistant } \\
\text { enterotoxin }\end{array}$ & $\begin{array}{l}\text { Food poisoning, and acute } \\
\text { diarrhea }\end{array}$ & $\begin{array}{l}\text { Food of animal origin, } \\
\text { bean products }\end{array}$ & {$[37,38]$} \\
\hline $\begin{array}{l}\text { Clostridium } \\
\text { botulinum }\end{array}$ & + & Botulinum toxoid & $\begin{array}{l}\text { Muscle relaxation } \\
\text { paralysis, and respiratory } \\
\text { paralysis }\end{array}$ & $\begin{array}{l}\text { Canned products, cured } \\
\text { meat }\end{array}$ & [39-41] \\
\hline Bacillus cereus & + & Enterotoxin & Food poisoning & $\begin{array}{l}\text { Leftovers of different } \\
\text { meals, commercial cold } \\
\text { food dishes }\end{array}$ & {$[7,42-44]$} \\
\hline Campylobacter & - & $\begin{array}{l}\text { Endotoxin, exotoxin, } \\
\text { invasive protein, } \\
\text { adhesion, and } \\
\text { flagellum }\end{array}$ & Bacterial gastroenteritis & $\begin{array}{l}\text { Raw chicken and } \\
\text { by-products }\end{array}$ & {$[45,46]$} \\
\hline
\end{tabular}

Rapid and accurate monitoring or detection of food borne pathogens is an international priority because accurate diagnosis is one of the most effective ways to control and prevent food borne epidemics in humans and can reduce mortality rates drastically [47]. Table 2 lists various conventional methods for food borne pathogens detection, which based on microbiological methods, immunological methods, or nucleic acid-based amplification assays (e.g., polymerase chain reaction [48], loop-mediated isothermal amplification [49], rolling circle amplification [50]). Although these methods are sensitive and allowed the detection of one single or multiple bacterium, there are still several key challenges that hinder their further development from laboratory detection stage to application in market $[51,52]$. Summarized as the following points: time-consuming; poor sensitivity and specificity; high detection cost; non-amenable for on-site and real-time diagnosis. Among these methods, biosensor strategies are highly prevalent over other assays and fulfill the expanding demands of modern industry for detection. In addition to fast response, robustness, cost-effectiveness, high sensitivity, and selectivity, they also have the ability to detect real sample on-site with minimal sample preparation [53]. 
A typical biosensor combines a bioreceptor with a transducer. The bioreceptor, which specifically interacts with the target analyte, and the transducer, which converts this interaction into an electronic signal. Three basic parts of a biosensor are recognition material, transducer or detector system, and signal processor [54]. According to bioreceptors, biosensors can be classified into antibody biosensors, DNA biosensors, enzyme biosensors, whole-cell biosensors, and phage biosensor; according to transducers, biosensors can be classified into electrochemical biosensors, piezoelectric biosensors, calorimetric biosensors, and optical biosensors (Figure 1). Among various biosensors, electrochemical DNA biosensor has become a ideal alternative of conventional methods for food borne pathogens detection, due to its features such as low detection limit, wide linear dynamic range, and high reproducibility [55]. Figure 2 shows the number of annual articles published on China National Knowledge Infrastructure (CNKI) for the detection of food borne pathogens by electrochemical DNA biosensors. The literature survey demonstrates more than 31,557 articles have been published since 1986. In the past 30 years, the total number of publications has increased dramatically. The data reveals the development of electrochemical DNA biosensors in the field of food borne pathogen detection has received extensive attention. There are a number of review articles that summarize the use of electrochemical DNA biosensors to detect a specific food borne pathology, or detecting food borne pathogens by using a large class of biosensors. However, there are few review articles summarizing previous studies on electrochemical DNA biosensors for detecting food borne pathogens.

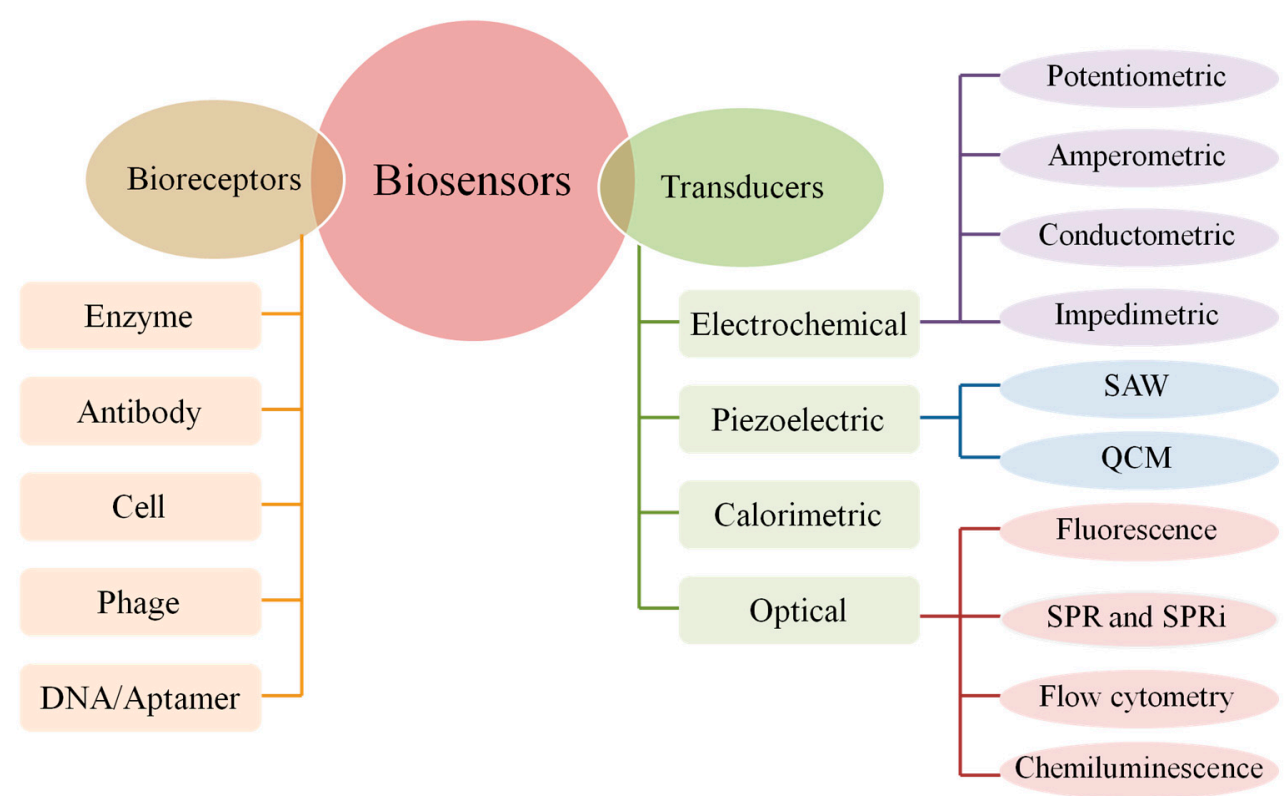

Figure 1. Components and classification of biosensor. 
Table 2. Current methods for food-borne pathogens detection.

\begin{tabular}{|c|c|c|c|c|c|}
\hline Method & Derivative & Analysis Time & Advantages & Disadvantages & Refs. \\
\hline $\begin{array}{l}\text { Traditional } \\
\text { microbiological } \\
\text { culture }\end{array}$ & $\begin{array}{l}\text { Chromogenic } \\
\text { medium method }\end{array}$ & 5-7 days & High accuracy & $\begin{array}{l}\text { Time-consuming, } \\
\text { laborious, poor } \\
\text { sensitivity and } \\
\text { specificity }\end{array}$ & {$[56,57]$} \\
\hline $\begin{array}{l}\text { Immunological } \\
\text { method }\end{array}$ & $\begin{array}{l}\text { ELISA, } \\
\text { immunomagnetic } \\
\text { separation (IMS), } \\
\text { immune colloidal } \\
\text { gold technique } \\
\text { (GICT) }\end{array}$ & $4 \mathrm{~h}$ & $\begin{array}{l}\text { Rapid, } \\
\text { relatively high } \\
\text { sensitivity and } \\
\text { specificity }\end{array}$ & $\begin{array}{l}\text { High false } \\
\text { positive rate } \\
\text { and poor } \\
\text { stability }\end{array}$ & [58-63] \\
\hline PCR & $\begin{array}{l}\text { Real time-PCR, } \\
\text { multiple PCR }\end{array}$ & $\leq 2 \mathrm{~h}$ & $\begin{array}{l}\text { Relatively } \\
\text { sensitive and } \\
\text { rapid, multiple } \\
\text { detection }\end{array}$ & $\begin{array}{l}\text { The need of } \\
\text { expensive } \\
\text { thermal cycle } \\
\text { instruments } \\
\text { and trained } \\
\text { users }\end{array}$ & [64-69] \\
\hline $\begin{array}{l}\text { Nucleic } \\
\text { acid-based } \\
\text { isothermal } \\
\text { amplification } \\
\text { assays }\end{array}$ & $\begin{array}{l}\text { LAMP, rolling circle } \\
\text { amplification (RCA), } \\
\text { saltatory rolling } \\
\text { circle amplification } \\
\text { (SRCA) }\end{array}$ & $\leq 2 \mathrm{~h}$ & $\begin{array}{l}\text { No need for } \\
\text { thermal cycle } \\
\text { instruments, } \\
\text { high sensitivity } \\
\text { and selectivity }\end{array}$ & $\begin{array}{l}\text { Not suitable for } \\
\text { on-site } \\
\text { detection }\end{array}$ & [70-73] \\
\hline Biosensors & $\begin{array}{l}\text { Based on signal } \\
\text { amplification } \\
\text { techniques such as } \\
\text { nanotechnology }\end{array}$ & $\leq 2 \mathrm{~h}$ & $\begin{array}{l}\text { Rapid, } \\
\text { cost-effective, } \\
\text { high sensitivity } \\
\text { and selectivity }\end{array}$ & $\begin{array}{l}\text { Most cannot } \\
\text { achieve } \\
\text { multiple } \\
\text { detection }\end{array}$ & [74-78] \\
\hline
\end{tabular}

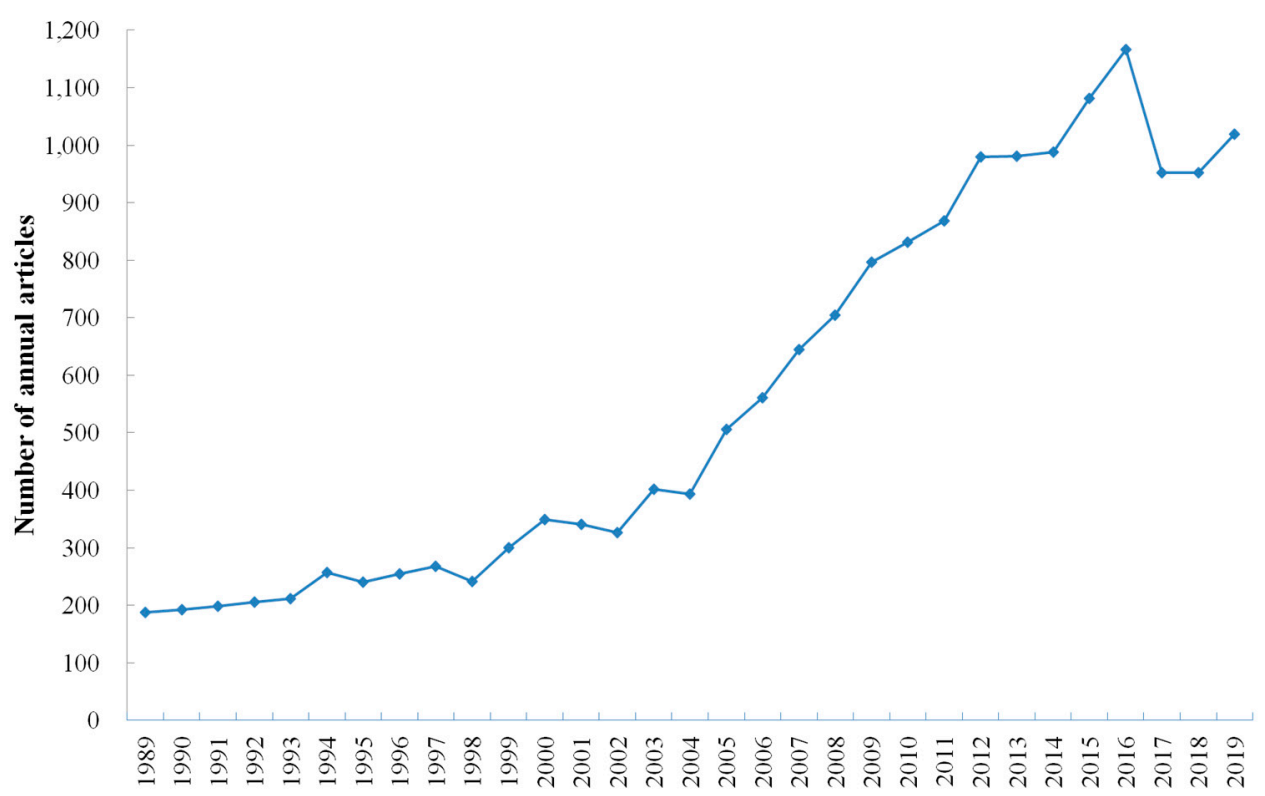

Figure 2. Number of publications for food borne pathogens detection with electrochemical DNA biosensors.

Therefore, the present review overviews extensive and up-to-date findings of electrochemical DNA biosensors for detecting food borne pathogens, summarizes the basic principle of an electrochemical DNA biosensor, DNA immobilization methods, electrochemical techniques, and detection methods. Besides, because sensitivity is a critical performance for electrochemical DNA biosensors, we also summarized several strategies for improving the sensitivity of electrochemical DNA biosensors, such 
as nucleic acid-based amplification technologies, which are rarely summarized in reviews. Finally, we predicted the future prospective in the field of pathogen detection.

\section{Electrochemical DNA Biosensors}

\subsection{Basic Principle of Electrochemical DNA Biosensors}

In the detection of food borne pathogens, single-stranded nucleic acids or aptamers are the preferred bioreceptor to be used in the design of electrochemical DNA biosensor. The most common transducers are gold electrodes (GE) [79-81], glassy carbon electrodes (GCE) [82], pencil graphite electrodes (PGE) [76] and screen printed electrodes (SPE) [83,84], and carbon ionic liquid electrode (CILE) [85]. The reaction between bioreceptor and target is performed on the electrode surface. The basic principle of electrochemical DNA biosensor is that the biological reaction between bioreceptor and target can produce or consume ions or electrons, which changes the electric current, potential, or other electrical properties of the solution. The biological signal can be converted into a detectable electrical signal proportional to target concentration by transducer and displayed on a computer [86]. The basic scheme of an electrochemical DNA biosensor is presented in Figure 3.

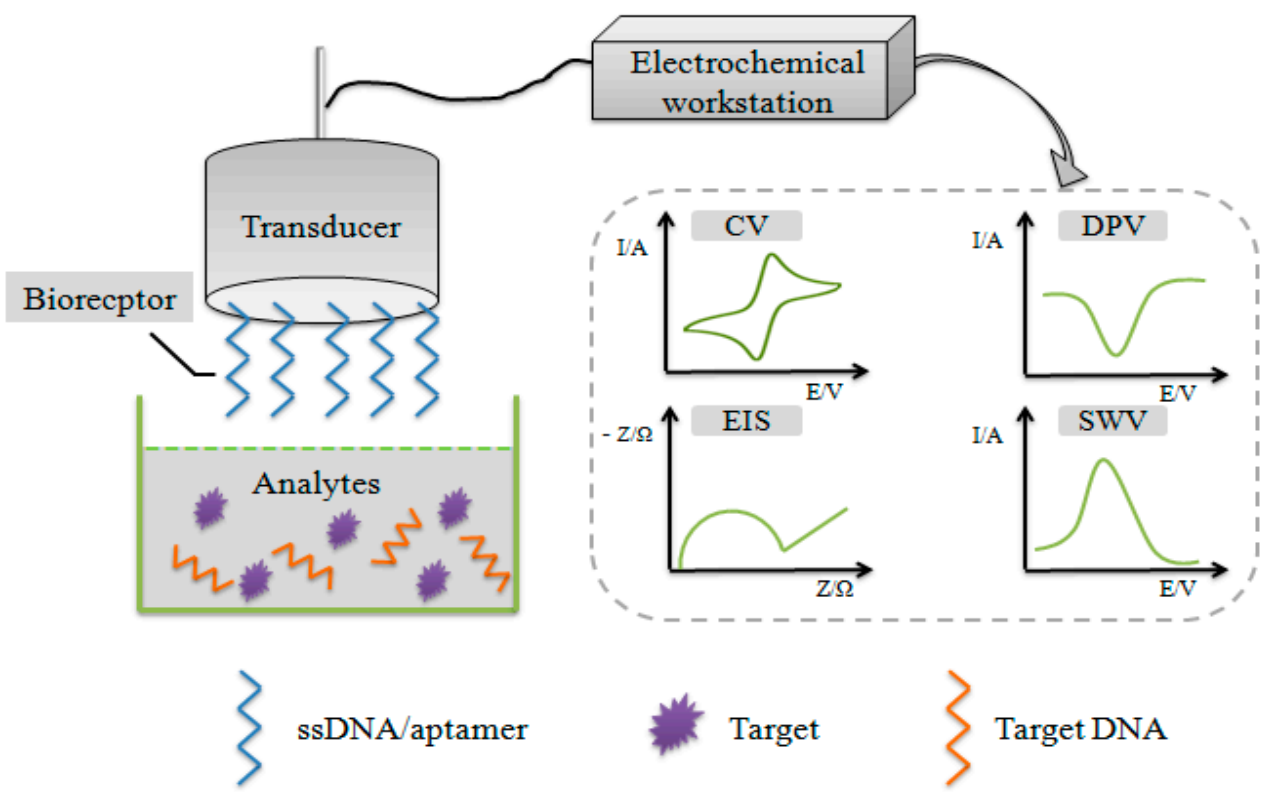

Figure 3. Schematic diagram of electrochemical DNA biosensors.

\subsection{Bioreceptor of Electrochemical DNA Biosensor}

\subsubsection{Type of Bioreceptor}

For electrochemical DNA biosensors, the bioreceptor is DNA. DNA consists of two types: naturally occurring recognition element DNA and aptamer artificially synthesized in vitro with a known sequence of bases. Biosensors regarding naturally occurring DNA as bioreceptors are called 'genosensors'. Typically, targets for such sensors are DNA of pathogens. The DNA probes immobilized on electrode surface can recognize and hybridize with targets DNA by complementary base pairing. Targets can also be recognized and captured by aptamers involving high-molecular-weight compounds, whole cells, and small molecules. Biosensors considering aptamer as bioreceptors are called "aptasensors" [86]. We attribute the high specificity of electrochemical DNA biosensors to strong affinity of ssDNA or aptamer and its target. 
Advantages of Aptamer

Aptamers are single-stranded DNA or RNA with 15-80 mononucleotides by artificial synthesis in vitro or peptide screened by SELEX (systematic evolution of ligands by exponential enrichment) $[87,88]$. The binding pattern between the aptamer and its target is similar to that of antigen-antibody, but aptamers have outstanding merits over their corresponding antibodies mainly involving in the following three points:

(1) Target diversity: It possesses the capability to bind with a wide range of targets (e.g., proteins, drugs, cell, amino acids, organic, and inorganic ions) by naturally fold into three-dimensional structures with high affinity and specificity [86,89-92].

(2) As amplifiable molecules: Due to the property of nucleic acids, aptamers can be amplified by polymerase chain reaction (PCR). Currently, several studies have applied this aptamer feature to improve the sensitivity of aptasensors based on real-time PCR [93,94], LAMP [95], RCA [96-98], et al.

(3) Low cost: Aptamers are stable even in drastic environmental conditions and not require special transport or storage conditions; aptamers can be prepared on a large scale by simple chemical synthesis with inexpensive nucleotides [99]. In addition, biosensors regarding aptamers as recognition elements have long lifetime, reducing the cost of detection.

\section{Detection Mechanisms of Aptamers with their Targets}

Aptamers are often considered as bioreceptors in the strategy of electrochemical DNA biosensors. When recognizing and capturing targets, aptamers fold into a three-dimensional formation. Because the elongated primary molecular structure of aptamers is unfavorable in energy and not stable, some unpaired nucleobases interact with each other to generate secondary structural motifs. The interactions of these motifs lead to more complex tertiary structures. Typical tertiary motifs are coaxial stacking and G-quadruplexes. Three different detection mechanisms are commonly applied in electrochemical DNA biosensors design for food borne bacteria detection:

(1) Direct binding mechanism: The aptamer immobilized on the electrode surface binds to target directly, causing a conformation change of aptamer, and then the current signal changes.

(2) Target-induced dissociation mechanism (TID) [88,100]: In the absence of target, the aptamer hybridizes with its complementary sequence. While the addition of target induces dissociation and replacement of the complementary sequence from the aptamer, making its complementary sequence free again and changing the electrochemical signal.

(3) Dual aptamer detection mechanism: Usually be employed in the design of sandwich-type aptasensors. In this case, the first aptamer is immobilized on sensing interface as capture probe to bind with the target and the second aptamer acts as a signal probe.

\subsubsection{Immobilization Methods of Bioreceptor}

The properties of electrochemical DNA sensors-including sensitivity, specificity, and lifetime-are largely related to the immobilization of bioreceptors on the surface of electrodes. Therefore, the most basic requirements for the immobilization method is that it neither destroy the biological activity of the bioreceptor nor affect the interaction between the bioreceptor and the target. Table 3 describes the principles, advantages, and disadvantages of three basic immobilizing methods of DNA.

Among various DNA immobilization methods, adsorption is the simplest, and it does not require any chemical reagents and DNA modifications. The phosphate backbone of DNA is negatively charged, and DNA can be immobilized by modifying positively charged substance on the electrode surface [101]. Such substances usually include chitosan, cationic polymeric films, etc. In addition, studies have shown that applying a positive potential to the electrode can make the DNA immobilization more stable. Vijayalakshmi Velusamy et al. [102] reported an electrochemical DNA biosensor to detect Bacillus cereus DNA. The gold electrode surface was modified with polypyrrole (PPy) to immobilize 
DNA, and then a fixed potential $0.8 \mathrm{~V}$ for $600 \mathrm{~s}$ was applied to enhance the immobilization efficiency and stability.

Table 3. Common methods of DNA immobilization.

\begin{tabular}{cll}
\hline Methods & \multicolumn{1}{c}{ Principle } & Evaluation \\
\hline Adsorption & $\begin{array}{l}\text { The skeleton of ssDNA is negatively } \\
\text { charged, by modifying the surface of } \\
\text { electrodes with positively charged } \\
\text { substances or applying a positive potential, } \\
\text { DNA can be absorbed on the electrodes. }\end{array}$ & $\begin{array}{l}\text { Simple, with no need of any } \\
\text { chemical reagents and DNA } \\
\text { probes modification [101]. Low } \\
\text { DNA hybridization efficiency. }\end{array}$ \\
\hline Covalent binding & $\begin{array}{l}\text { DNA is immobilized on the surface of } \\
\text { electrodes through the formation of } \\
\text { covalent bonds such as amide bonds, ester } \\
\text { bonds, ether bonds, Au-S, and Ag-S et al. }\end{array}$ & $\begin{array}{l}\text { Flexible structure, high efficiency } \\
\text { of DNA immobilization and } \\
\text { hybridization, but with the need of } \\
\text { chemical reagents, and with the } \\
\text { possibility of non-specific } \\
\text { adsorption. }\end{array}$ \\
\hline Affinity binding & $\begin{array}{l}\text { Avidin is first adsorbed on the surface of the } \\
\text { electrode by covalent binding or } \\
\text { electrostatic adsorption, and then the } \\
\text { biotin-modified DNA is immobilized on the } \\
\text { electrode by affinity interaction between } \\
\text { biotin and avidin. }\end{array}$ & $\begin{array}{l}\text { The method is simple, stable and } \\
\text { resistant to the extreme of } \\
\text { temperature, pH, denatured } \\
\text { detergents, and organic } \\
\text { solvents [101]. }\end{array}$ \\
\hline
\end{tabular}

Due to high efficiency of DNA immobilization and hybridization, covalent binding is one of the most common methods for DNA immobilization on electrode surfaces. Mahmoud Amouzadeh Tabrizi et al. [103] developed an electrochemical DNA biosensor based on nanoporous glassy carbon electrodes to detect Salmonella DNA sequences. The amino modified probe DNA was firstly covalently linked with carboxylic group on the nanoporous GCE. Then target DNA hybridized with the probe DNA and the hybridization result was obtained by DPV and EIS techniques. The LOD of the biosensor was $2.1 \mathrm{pM}$ and $0.15 \mathrm{pM}$, respectively. Besides, self-assembly is another common covalent bond method for DNA immobilization on the electrode surface. Zahra Izadi et al. [76] developed an electrochemical DNA biosensor to detect Bacillus cereus in milk and infant formula. Before introducing DNA to the biosensor, they thiolated the $5^{\prime}$ end of ssDNA to immobilize ssDNA on PGE surface modified with gold nanoparticles by Au-S bonds. The biosensor sensitivity of B. cereus was found to be $100 \mathrm{CFU} / \mathrm{mL}$. E. Sheikhzadeh et al. [104] established a label-free impedimetric biosensor to detect S. Typhimurium in apple juice. Modifying the amino group at the $5^{\prime}$ end of aptamer before immobilizing on electrode surface. LOD of developed biosensor was $3 \mathrm{CFU} / \mathrm{mL}$, which achieved a satisfying detection result.

One of the most valuable strategies for the effective immobilization of DNA on electrodes is affinity binding. This method is dependent on the specific affinity between avidin and biotin. However, compared with other methods, LOD of the electrochemical DNA biosensor established by this method is low. For example, Kavita Arora et al. [105] constructed an electrochemical DNA biosensor based on polypyrrole-polyvinyl sulfonate (PPy-PVS) coated onto Pt disc electrode. DNA probe was immobilized on electrode by biotin-avidin binding (indirect immobilization) or carbodiimide coupling (direct immobilization). Compared to the indirect immobilization, the detection limit of direct immobilization of the probe increased by 2200 times and the sensitivity increased by about 6 times. In order to solve this problem, several studies have combined covalent binding and affinity binding to improve DNA immobilization efficiency. For instance, Malhotra et al. [106] developed an electrochemical DNA biosensor to detect $E$. coli. Avidin was modified with $-\mathrm{COOH}$ and then attached to the polyaniline (PANI)-modified Pt disk by the covalent binding between - $\mathrm{COOH}$ and $-\mathrm{NH} / \mathrm{NH}_{2}$ of PANI. Thereby, the biotin-labeled capture probe was immobilized on electrode surface by the affinity binding. Finally, a satisfactory detection limit for E. coli genomic DNA $(0.01 \mathrm{ng} / \mathrm{uL})$ was obtained. 


\subsection{Electrochemical Techniques}

Due to the lower tendency for noise, voltammetry has developed into one of the most versatile electrochemical analysis techniques. The current is measured in a constant potential imposed to work electrode. Peak current intensity is proportional to the target concentration. More importantly, it is adapted to all types of bioreceptors [51].

Among the voltammetry techniques, cyclic voltammetry (CV), square wave voltammetry (SWV), and differential pulse voltammetry (DPV) are the most frequently employed. CV is often used to characterize chemical reactions and electrochemical coupling process on electrode surface. SWV, as a type of frequency dependent electrochemical analysis technique, is versatile and highly sensitive, which is widely used in quantitative analysis and kinetic studies of materials. Besides, the peak shape of SWV is simple and convenient for data analysis. DPV possesses the merits of lower background current and higher sensitivity, almost all electrochemical DNA biosensors regard DPV as an analysis technique for determining target concentration.

Another electrochemical technique generally applied to electrochemical DNA biosensors is electrochemical impedance spectroscopy (EIS). In this technique, impedance values are affected by the electric field changes caused by the interaction between bioreceptor and target [51]. EIS is a frequency domain measurement technique with a wide range of measurable frequencies, which allows more kinetic information and electrode interface structure information to be obtained than conventional electrochemical techniques. Table 4 listed several electrochemical techniques commonly used in electrochemical DNA biosensors for detecting food borne pathogenic bacteria.

Table 4. Electrochemical techniques.

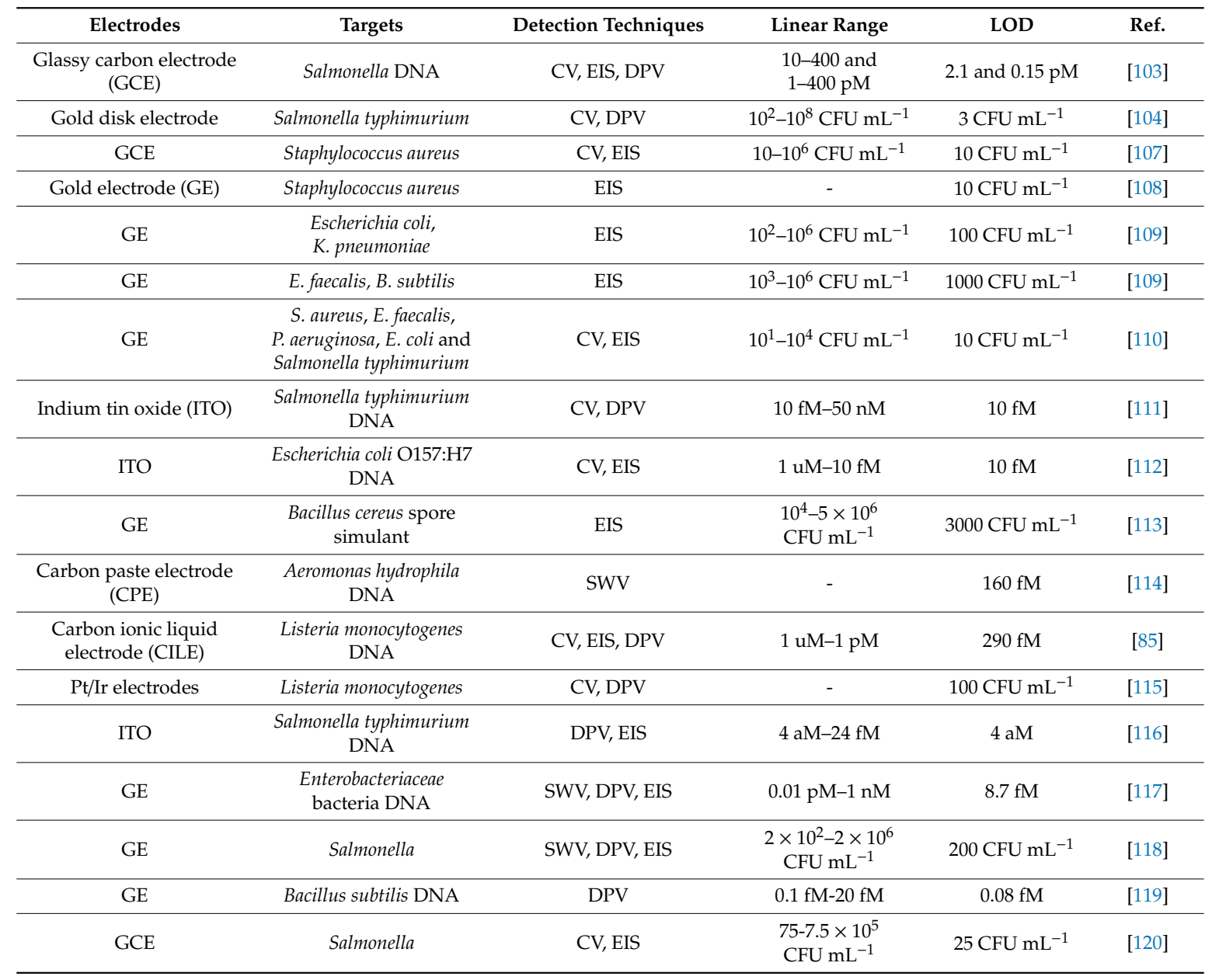


Table 4. Cont.

\begin{tabular}{|c|c|c|c|c|c|}
\hline Electrodes & Targets & Detection Techniques & Linear Range & LOD & Ref. \\
\hline ITO & Salmonella typhimurium & CV, EIS & - & $10 \mathrm{CFU} \mathrm{mL}^{-1}$ & [121] \\
\hline $\begin{array}{l}\text { Pencil graphite electrode } \\
\text { (PGE) }\end{array}$ & Bacillus cereus & DPV, EIS & $10^{0}-10^{7} \mathrm{CFU} \mathrm{mL}^{-1}$ & $9.4 \mathrm{pM}$ & [76] \\
\hline CILE & $\begin{array}{c}\text { Yersinia enterocolitica } \\
\text { DNA }\end{array}$ & DPV & $1 \mathrm{uM}-10 \mathrm{PM}$ & $1.76 \mathrm{pM}$ & [122] \\
\hline GCE & E. coli O157:H7 DNA & CV, EIS, DPV & - & $19.7 \mathrm{fM}$ & [79] \\
\hline GE & Salmonella typhimurium & DPV & $\begin{array}{l}72-7.2 \times 10^{6} \\
\text { CFU mL }{ }^{-1}\end{array}$ & $28 \mathrm{CFU} \mathrm{mL}^{-1}$ & [123] \\
\hline GCE & DNA & ASV, EIS & - & $100 \mathrm{aM}$ & [124] \\
\hline
\end{tabular}

\subsection{Detection Methods}

DNA hybridization detection methods can be classified into label-free and label-based methods [101]. For label-free electrochemical DNA biosensors, DNA's own structure and composition are of paramount advantageous for electrochemical detection. Adenine and guanine of DNA can be easily oxidized within a certain potential range, thymine and cytosine require higher potential for oxidation, so electron transfer can be performed directly on several electrode surfaces $[125,126]$. Even the sensing strategy based on direct redox reaction of nucleic bases has a high sensitivity, the large background current interference limits its application [101]. The oxidation reaction of ribose destroys the phosphate backbone of DNA, it is rarely used for DNA-modified electrodes.

For label-based electrochemical DNA biosensors, numerous studies introduced redox active molecules as indicators to promote electron transfer between the electro-active base and the electrode surface. DNA was detected indirectly by measuring the electrical signals generated by the modified substances. Sensitivity of this method is much higher than that of strategy based on direct redox reaction of nucleic bases [127]. Three selection requirements for redox active indicators are summarized below. (a) Indicators cannot affect the activity of bioreceptors and cannot react with the electrode material itself. (b) Possessing the ability to bind with ssDNA or dsDNA selectively. (c) Cannot adsorb on the sensing surface. According to the above requirements, we summarized several redox active molecules applied to electrochemical DNA biosensors (Table 5).

Both Zahra Izadi et al. [76] and Wei Sun et al. [85] used methylene blue (MB) as the electroactive indicator to detect DNA hybridization efficiency, because MB can intercalated into the dsDNA structure and reaction signal was improved [54]. TB can bind to the negatively charged phosphate group of DNA. R. Nazari-Vanani et al. [80] employed this feature to examine the hybridization reaction between Enterococcu faecalis DNA and capture DNA. The study showed that TB binds with dsDNA in a higher extent compared to ssDNA. Thus, ssDNA and dsDNA structures on the surface of electrodes can be distinguished through the peak current. Besides, a electrochemical nanobiosensor was constructed by Mostafa Azimzadeh et al. [128] using oracet blue (OB) as an electroactive label for the first time. OB, an organic dye, has a hydrophobic rigid plane which can insert into the dsDNA base pair, causing the reduction signals to change.

Hoechst 33258 is mainly combined with minor and major groove only existing in dsDNA. For daunomycin, its molecular carbocyclic moiety can be inserted into the base pair of the DNA helix, and its amino sugar moiety generate electrostatic interaction with the phosphate. M. Ligaj et al. [114] utilized the features of Hoechst 33258 and daunomycin to develop two electrochemical DNA biosensors for Aeromonas hydrophila detection. After hybridization between DNA probes immobilized on the surface of biosensors and the target DNA, the peak currents of biosensor I used Hoechst 33258 as the indictor increased by $75-135 \%$ and the other increased by $34-92 \%$. Additionally, because $\mathrm{Ru}(\mathrm{phen})_{3}{ }^{2+}$ can intercalate into the groove of dsDNA, it is another redox indicator commonly used to detect the DNA hybridization event. For example, Huayu Huang et al. [129] selected $\mathrm{Ru}(\mathrm{phen})_{3}{ }^{2+}$ as a 
redox indicator to amplify electrochemical signal. Linlin Yang et al. [97] also used it to enhance the electrochemiluminescence intensity.

There are also several studies employing enzyme label-based electrochemical detection to construct direct or sandwich DNA hybridization biosensors to detect food borne pathogenic bacteria. In this method, the electrochemical signal can be amplified since the enzymes can catalyze its electroinactive substrate into electroactive products [101]. The particular redox-active enzymes typically include horseradish peroxide and alkaline phosphate. Generally, the redox-active enzymes combine with DNA by the affinity binding of biotin-avidin/streptavidin. For example, a sandwich DNA hybridization genosensor was developed for Salmonella detection [130]. Interestingly, this study used AuNPs-horseradish peroxidase-streptavidin (AuNPs-HRP-SA) as the signal tag to amplify the detection signal. SA biofunctionalized HRP bind to the biotinylated DNA by affinity. In the presence of $\mathrm{H}_{2} \mathrm{O}_{2}$ and hydroquinone (HQ), the electrochemical signal was generated. Because hydroquinone (HQ) acted as a redox mediator, HRP can catalytic $\mathrm{H}_{2} \mathrm{O}_{2}$ to reduce. In another study, Chuang Ge et al. [100] constructed an aptasensor to ultra-sensitively determine Salmonella typhimurium. Streptavidin-alkaline phosphatase (ST-AP) was used as the label enzyme to combine with the biotinylated detection probe by the affinity. The electrochemical signal was improved by catalytic activity ST-AP towards enzyme substrate $\alpha$-NP. Even enzyme label-based electrochemical detection is used widely, high cost of enzyme production and the instability of enzymes limit its further development [101].

Table 5. Redox active molecules applied in electrochemical DNA biosensors

\begin{tabular}{|c|c|c|c|c|}
\hline Redox Active Molecule & Classification & Target & Principle & Refs. \\
\hline Methylene Blue (MB) & Organic dye & $\begin{array}{l}\text { Bacillus cereus; } \\
\text { Listeria } \\
\text { monocytogenes }\end{array}$ & $\begin{array}{l}\text { MB covalently interacts with } \\
\text { G bases of DNA }\end{array}$ & {$[76,85]$} \\
\hline Toluidine Blue (TB) & Organic dye & Enterococcus faecalis & $\begin{array}{l}\text { TB binds to a negatively } \\
\text { charged phosphate group }\end{array}$ & [80] \\
\hline Oracet Blue (OB) & Organic dye & Helicobacter pylori & $\begin{array}{l}\text { The hydrophobic rigid plane } \\
\text { of OB inserts into the } \\
\text { dsDNA base pair }\end{array}$ & {$[128,129,131]$} \\
\hline Hoechst 33258 & Organic dye & Aeromona hydrophila & $\begin{array}{l}\text { Hoechst } 33258 \text { can bind to } \\
\text { dsDNA by minor and major } \\
\text { groove interaction }\end{array}$ & [114] \\
\hline$\left[\mathrm{Ru}(\text { phen })_{3}\right]^{2+}$ & Metal complex & Aeromona hydrophila & $\begin{array}{l}\mathrm{Ru}(\mathrm{phen}) 3^{2+} \text { can intercalate } \\
\text { into the groove of dsDNA }\end{array}$ & {$[97,129]$} \\
\hline Daunomycin & Drug molecular & Aeromona hydrophila & $\begin{array}{l}\text { The molecular carbocyclic } \\
\text { moiety can be inserted into } \\
\text { the base pair of the DNA } \\
\text { helix, and the amino sugar } \\
\text { moiety generate electrostatic } \\
\text { interaction with the } \\
\text { phosphate backbone of the } \\
\text { DNA }\end{array}$ & [114] \\
\hline
\end{tabular}

Besides those, nanoparticles commonly act as the reporter labels to characterize the DNA hybridization. Most of the previous studies applied this approach to sandwich genosensors. In the sensors, target DNA will co-hybridize with both of capture probe immobilized on the electrode surface and signal probe labeled with nanoparticles. For instance, a sandwich electrochemical genosensor using cadmium sulfide nanoparticles (CdSNPs) as a label was established by Mandour H. Abdalhai et al. [79] to detect Escherichia coli O157:H7. The signalizing probes were modified by amine $\left(\mathrm{NH}_{2}\right)$ and then attached to CdSNPs by covalent binding. Finally, the sandwich structure immobilized on the electrode surface was dissolved in $\mathrm{HNO}_{3}$ solution, then the released CdSNPs ions were ready for electrochemical measurement. Although the method is highly sensitive, the detection method, including chemical synthesis of nanoparticles, is extremely cumbersome. 


\section{Strategies for Improving the Sensitivity of Electrochemical DNA Biosensors}

Sensitivity is a critical performance for electrochemical DNA biosensors. When detecting targets with low concentration, the reaction signal is difficult to distinguish from the background signal due to the small amount and the limitation of method itself, resulting in inaccurate detection results. Thus, in the past few decades, researchers have made enormous efforts into integrating biosensors with other disciplines such as nanotechnology and molecular biology technology to improve the sensitivity. Herein, we summarized various nanomaterials and DNA amplification technologies employed widely to improve the sensitivity of electrochemical DNA biosensors.

\subsection{Nanomaterials}

Recently, in view of their intrinsic properties—such as high surface area to volume ratio, great electronic conductivity, and excellent physico-chemical properties, carbon nanomaterials (containing carbon nanotubes, carbon nanofibers, graphene, nanoparticles et al.) - as a class of promising candidate for biosensing material, have successfully been applied to sensing strategies to improve the sensitivity of electrochemical DNA biosensors [47]. Figure 4 shows several nanomaterials of different dimensions $(0 \mathrm{D}, 1 \mathrm{D}, 2 \mathrm{D}, 3 \mathrm{D})$ commonly used in electrochemical DNA biosensors for food borne pathogen detection.

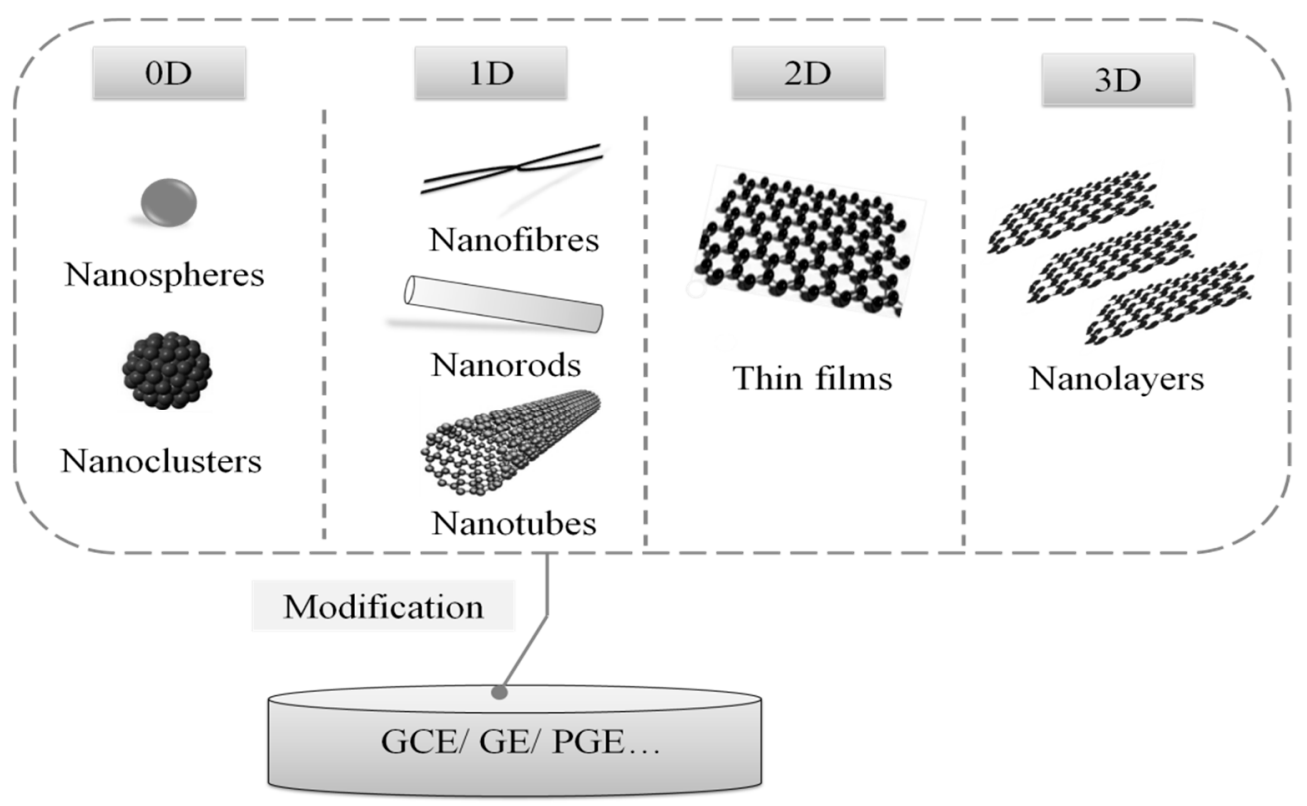

Figure 4. Nanomaterials commonly used in the modification of electrochemical DNA biosensors.

\subsubsection{Conventional Nanomaterials}

Reduced graphene oxide (RGO), gold nanoparticles (AuNPs) and carbon nanotubes (CNTs) are the three most common nanomaterials modified on electrodes.

Graphene has large specific surface area, outstanding biocompatibility and highest mechanical strength in known materials. However, many studies introduced RGO to electrode surface, because graphene has the irreversible agglomeration, which limited its application [82,132-134]. The abundant oxygenated groups (hydroxyl, epoxy, carbonyl, and carboxyl groups) of graphene oxide (GO) reduce the electron transporting ability of the electrodes. So many studies employed several appropriate reduction methods to remove these oxygenated groups of GO [135].

Due to its small particle size, special stability and catalytic properties, AuNP is considered as the most favorite nanomaterial in the field of biosensors [135,136]. AuNPs provide substrates for DNA immobilization on the electrode surface, because DNA can be immobilized on the surface of the AuNPs-modified electrode by Au-S bonds. Besides, AuNPs can maintain the biological activity of 
DNA and enhance the capacity of DNA immobilization and hybridization [85]. Many studies have combined RGO and AuNPs to improve electrode performance synergistically $[85,107,135,137]$.

Since its discovery in 1991 [138], CNTs have received extensive attention in the field of electrochemical sensors due to its mechanical flexibility, rapid electron transfer, excellent electrochemical stability, and unique thermal conductivity. Additionally, CNTs are easily modified by various functional groups and bind with DNA, and so can be widely used in the construction of electrochemical DNA biosensors [139].

\subsubsection{Composite Nanomaterial}

Safiye Jafari et al. [140] constructed an electrochemical DNA biosensor based on Ceria nanoparticles decorated reduced graphene oxide $\left(\mathrm{CeO}_{2} \mathrm{NPs}-\mathrm{RGO}\right)$ to detect Aeromonas hydrophila DNA. Polyaniline and $\mathrm{CeO}_{2} \mathrm{NPs}-\mathrm{RGO}$ were used to modify the glassy carbon electrode. PANI provided a large surface area for DNA immobilization, and it can interact with RGO by $\Pi-\Pi$ stacking. RGO was also used for the DNA immobilization through $\Pi-\Pi$ stacking between its conjugated interface and DNA bases. Besides, $\mathrm{CeO}_{2}$ possessed high catalytic activity and biocompatibility, and can adsorb DNA through electrostatic attraction. Thus, in this study, ssDNA was immobilized on the GCE surface without any functionalization or mediators. $\left[\mathrm{Ru}(\mathrm{bpy})_{3}\right]^{2+/ 3+}$ redox signal was used as electrochemical marker and square wave voltammetry was used as detection technique. Finally, a wide linear range of $1 \times 10^{-15}-1 \times$ $10^{-8} \mathrm{~mol} \mathrm{~L}^{-1}$ and a low LOD of $1 \times 10^{-16} \mathrm{~mol} \mathrm{~L}^{-1}$ were obtained. The biosensing strategy can be applied to DNA detection in other area such as clinical diagnosis, food safety, and environmental monitoring.

Yange Sun and colleagues took advantage of chitosan-multiwalled carbon nanotubes (CS-MWCNTs) and gold nanoparticles (AuNPs) to modify an Au electrode (AuE) [141]. Chitosan own the merits of nontoxic nature, excellent film forming ability, and cost effectiveness. However, the electrical conductivity of CS is very poor. In this study, MWCNTs were utilized to dope into CS film to improve the electrical conductive properties of CS, because MWCNTs have the advantages of high electrical conductivity, chemical stability, and a high surface-to-volume ratio. AuNPs can provide a platform for DNA immobilization and can enhance the electrical conductivity with MWCNTs synergistically. The thiol-modified ssDNA was immobilized on the AuNPs/CS-MWCNTs/AuE by Au-S bonds and then hybridized with the target DNA. Methylene blue (MB) was used as an electrochemical indicator. In the end, this platform reached a detection limit of Staphylococcus aureus DNA as low as $3.3 \times 10^{-16} \mathrm{M}$ and the linear detection range was $1.0 \times 10^{-15}-1.0 \times 10^{-8} \mathrm{M}$.

In addition to the above proposed composite nanomaterials used in electrochemical DNA sensors, Table 6 lists several other nanocomposites applied in the sensing design to synergistically enhance the analysis performance of biosensors.

Table 6. Nanocomposites-based electrochemical DNA biosensors for food borne bacterial pathogen detections.

\begin{tabular}{|c|c|c|c|c|c|}
\hline Nanocomposites/Electrode & Features & $\begin{array}{l}\text { Immobilizing } \\
\text { Methods of DNA }\end{array}$ & Targets & $\operatorname{LOD}(\mathrm{mol} / \mathrm{L})$ & Ref. \\
\hline AgNCs/AuNPs/GCE & $\begin{array}{l}\text { AgNCs are used as } \\
\text { direct signal } \\
\text { indicator and AuNPs } \\
\text { as carrier for signal } \\
\text { amplification }\end{array}$ & $\begin{array}{l}\text { By the Au-S bonds } \\
\text { between AuNPs and } \\
\text { SH-DNA }\end{array}$ & Salmonella & $1.62 \times 10^{-16}$ & [142] \\
\hline $\mathrm{CTS} / \mathrm{V}_{2} \mathrm{O}_{5} / \mathrm{MWCN} / \mathrm{CILE}$ & $\begin{array}{l}\text { Great } \\
\text { biocompatibility of } \\
\mathrm{V}_{2} \mathrm{O}_{5} \text { nanobelt and } \\
\text { excellent electron } \\
\text { transfer ability of } \\
\text { MWCNTs }\end{array}$ & $\begin{array}{l}\text { CTS can be used for } \\
\text { DNA immobilization } \\
\text { by electrostatic } \\
\text { attraction }\end{array}$ & $\begin{array}{c}\text { Yersinia } \\
\text { enterocolitica }\end{array}$ & $1.76 \times 10^{-12}$ & [122] \\
\hline
\end{tabular}


Table 6. Cont

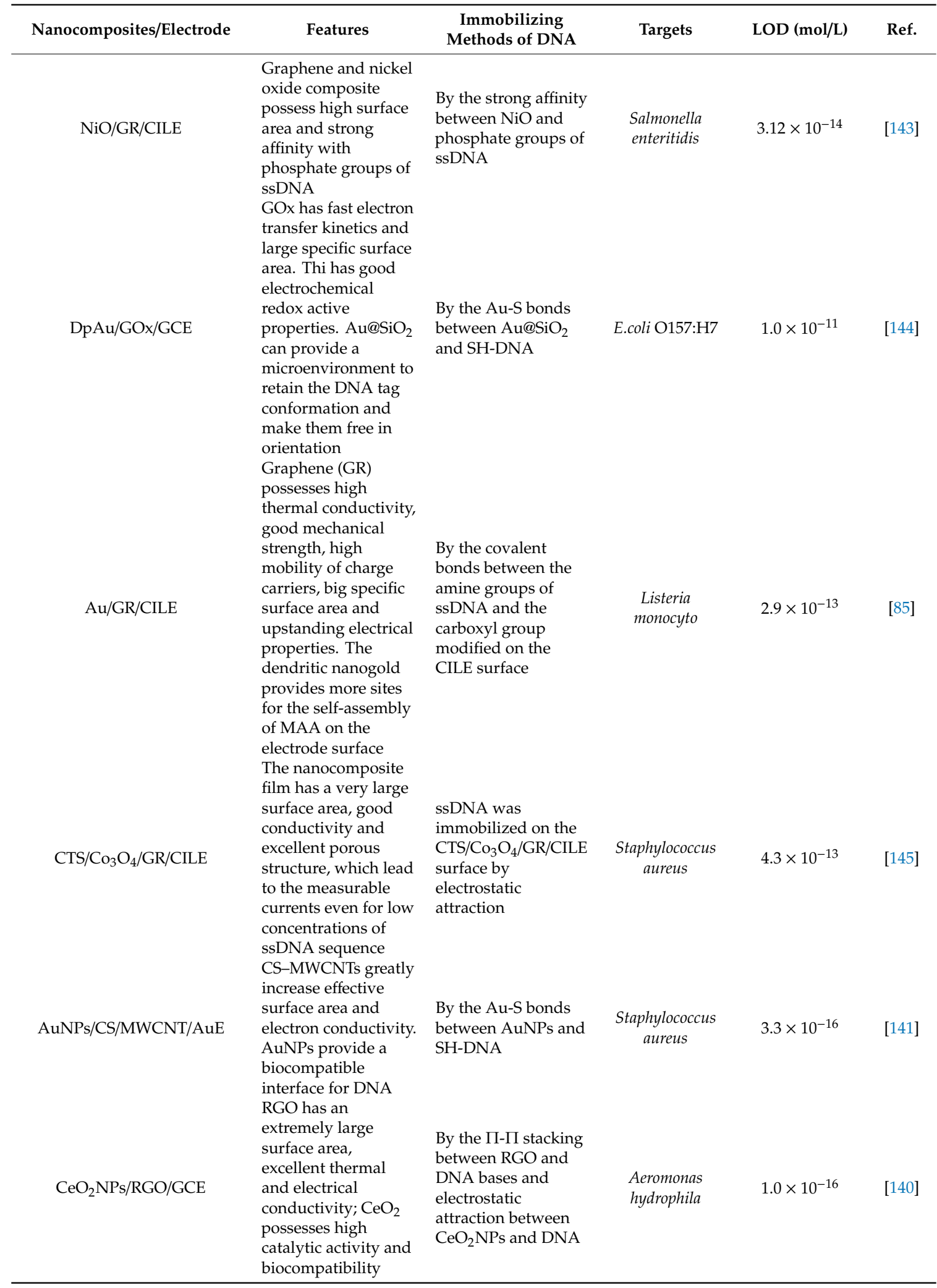

\subsubsection{Emerging Nanomaterials}

In recent years, several emerging nanomaterials were introduced to the design of electrochemical DNA biosensors for food borne pathogens detection. The emergence of these novel nanomaterials 
provides more choices for improving the sensitivity of electrochemical DNA biosensors and has greatly promoted the development of nanotechnology in the field of electrochemistry.

A electrochemical DNA biosensor was reported to detect Enterococcus faecalis, which based on a new gold nanostructure of ice crystals-like as the sensing substrate [80]. The nanostructure provided a suitable substrate for DNA immobilization and improved the rate of DNA hybridization. ssDNA was self-assembled on the Au/nano electrode surface by thiol-gold covalent bonds. Toluidine blue (TB) was used as the DNA hybridization indicator. The DNA biosensor can detect target DNA with a outstanding LOD of $4.7 \times 10^{-20} \mathrm{~mol} \mathrm{~L}^{-1}$.

In recent years, some studies have combined other novel nanomaterials with GO to improve the sensitivity simultaneously. Yan Li et al. developed an electrochemical DNA biosensor to detect E. coli O157:H7 eaeA gene based on a novel sensing tag of GOx-Thi-Au@SiO ${ }_{2}$ nanocomposites [144]. In this study, the combination of $\mathrm{Au} @ \mathrm{SiO}_{2}$ and $\mathrm{GO}$ can not only enhance electronic transfer, but it also offers a microenvironment to maintain the DNA conformation and free them in orientation. DNA was immobilized on the electrode surface by the Au-S bonds between ${\mathrm{Au} @ S i O_{2}}_{2}$ and $\mathrm{SH}-\mathrm{DNA}$. Due to these merits, the biosensor demonstrated a wide linear response for E. coli O157:H7 eaeA gene in the range from 0.02 to $50.0 \mathrm{nM}$ and the lowest detection limit was $0.01 \mathrm{nM}$. The developed biosensor can also apply to the detection of other pathogens with excellent performance.

\subsection{Nucleic Acid-Based Amplification Technologies}

Nucleic acid-based amplification technology is another promising alternative for electrochemical DNA biosensors to improve the sensitivity in the detection of food borne pathogens. The electrochemical DNA biosensors that integrated the powerful amplification capability of DNA amplification technology, the high sensitivity of electrochemical assays and various signal amplification strategies, are widely used in the ultrasensitive detection of trace targets. Here are several amplification methods commonly used in the construction of electrochemical DNA biosensors (Figure 5).

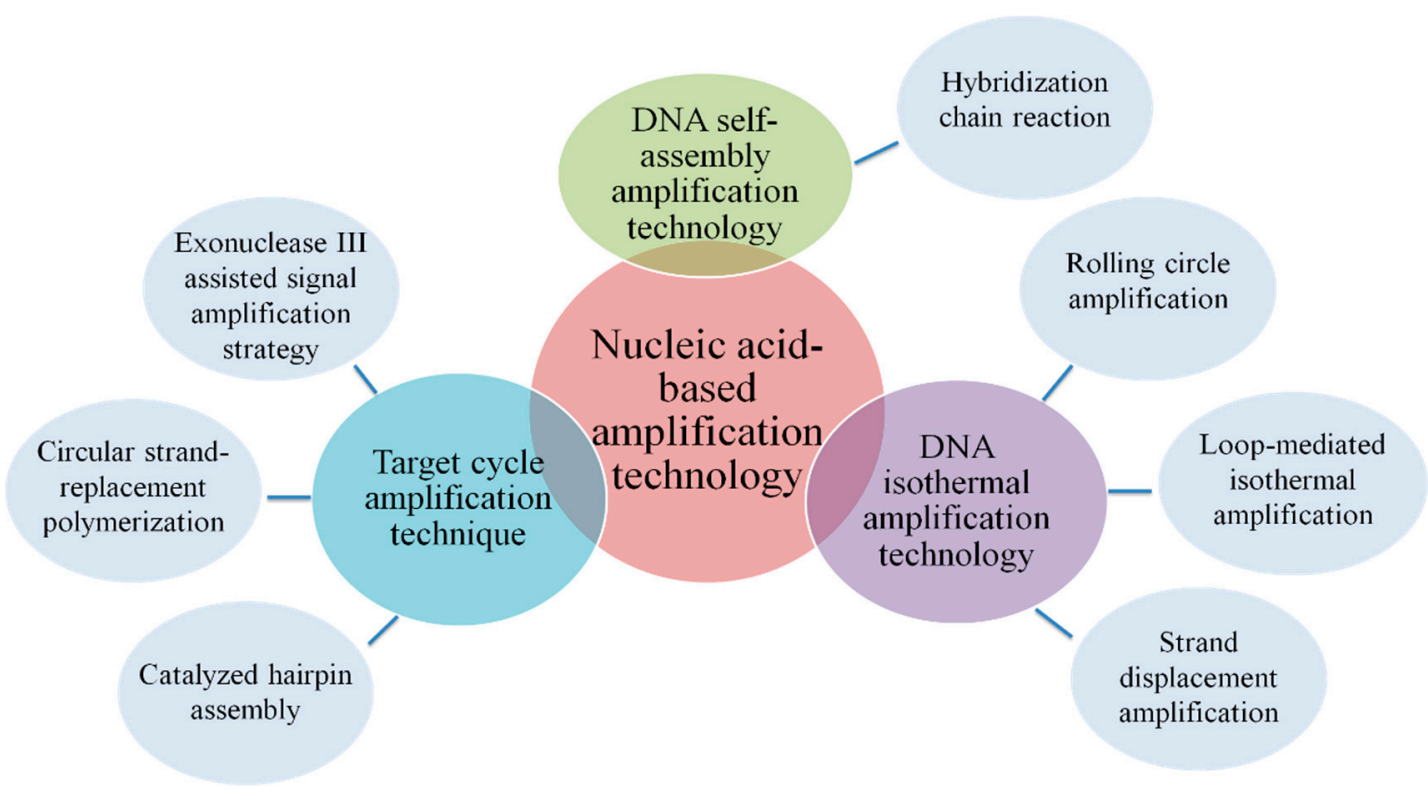

Figure 5. Classification of nucleic acid-based amplification technologies.

\subsubsection{Target Cycle Amplification Technique}

Exonuclease III-Assisted Target Cycle Amplification

Exonuclease III is a kind of enzyme which catalyze the stepwise removal of mononucleotides from $3^{\prime}$ terminus of dsDNA in the case of substrate with a blunt or recessed $3^{\prime}$-terminus. Compared 
with the endonuclease, exonuclease III is sequence-independent and can amplify a signal without a specific recognition site of target DNA, which has been widely applied in nucleic acid detection [117].

A sensitive electrochemical sensing methodology for quantitative detection of Enterobacteriaceae bacteria was proposed by Caihui Luo et al. [117]. As shown in Figure 6, in this strategy, thiol-modified capture probes were firstly immobilized on the gold electrode surface by Au-S bonds. $\mathrm{MCH}$ was used to block non-specific adsorption sites on the electrode surface. In the presence of a target, it hybridized with capture probes to generate dsDNA. The dsDNA possessed unique characteristic 3'-blunt end at the capture DNA and $3^{\prime}$-overhang end at target DNA. Hereafter, Exo III recognized and digested the phosphodiester bonds of the $3^{\prime}$ end of capture probes. Then target was released to perform the next hybridization and cleavage cycle. After finishing the entire amplification, the capture probes left on the electrode surface hybridized with biotinylated detection probes. ST-AP was indirectly linked to detection probe through the affinity between biotin and streptavidin, and then enzymatic electrochemical signal was produced. By DPV technique, the proposed biosensor lead to a superior LOD of $8.7 \times 10^{-15} \mathrm{~mol} / \mathrm{L}$ toward Enterobacteriaceae. The strategy was successfully applied to the detection of Enterobacteriaceae in milk with a ultra-low detection limit of $40 \mathrm{CFU} / \mathrm{mL}$.

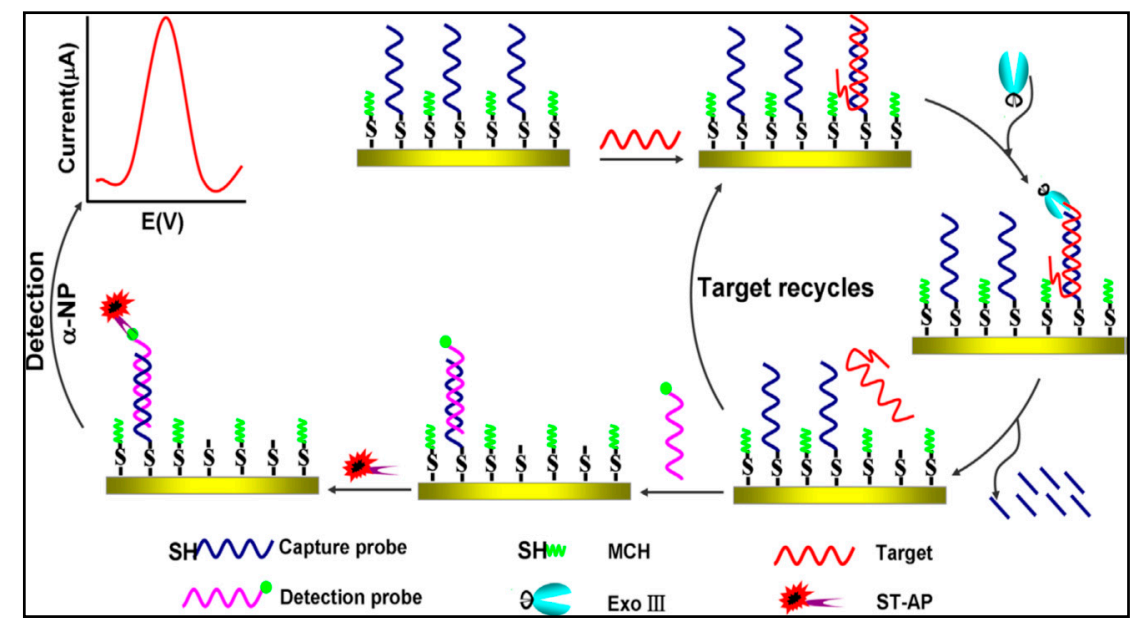

Figure 6. Electrochemical sensing methodology based on exonuclease III-assisted target recycling amplification technique for quantitative detection of Enterobacteriaceae bacteria [117]. Copyright 2013. Reproduced with permission from Elsevier B.V.

According to the similar principle, Qianqian Pei et al. constructed a universal DNA biosensing platform to detect $S$. Typhimurium ultra-sensitively [123]. The uniqueness in their works that a duplex DNA probe was ingeniously designed by hybridizing a Salmonella typhimurium aptamer with a primer. In the presence of Salmonella typhimurium, the three-dimensional conformation of aptamer changed to bind with targets. Then primer was released and Exo III-aided amplification reaction was initiated. Another difference is that MB was used to enhance the electrochemical signal in this platform. An excellent LOD of $2.8 \times 10 \mathrm{CFU} / \mathrm{mL}$ was obtained by DPV, which is lower than those of the previously proposed assays.

\section{Circular Strand-Replacement Polymerization}

Circular strand-replacement polymerization (CSRP) performs an isothermal amplification process under the action of DNA polymerase by utilizing a stem-loop DNA as template and target DNA as trigger. Firstly, target DNA hybridizes with loop structure, opening the stem-loop DNA, and resulting in exposure of the primer binding region. In the presence of primer, dNTPs, and DNA polymerase, the primer extends forward along DNA probe and displaces target DNA. The displaced target DNA triggered another round of primer extension and strand displacement. CSRP has been widely used to signal amplification strategies since it does not require any specific recognition sites. 
Based on the CSRP principle, Ting Wang et al. developed an ultrasensitive electrochemical DNA biosensor to detect mecA gene of methicillin-resistant Staphylococcus aureus [146]. From Figure 7, we can observe hairpin probes modified with $\mathrm{MB}$ were firstly immobilized on gold electrode surface by $\mathrm{Au}-\mathrm{S}$ bonds. $\mathrm{MB}$ is an electrochemically active molecule, a large current will be generated when it is restricted close to the electrode surface. When targets were present, the stem-loop probes were opened to expose the primer binding area and its loop area hybridized with targets. In the action of dNTPs and polymerase, the primers extended along probe DNA to displace the targets. The released targets induced the next amplification. In the end, a plenty of duplex DNA complexes labeled with MB were produced. The MB molecules moved away from the electrode surface, resulting in a significant decrease in current. There was a linear relationship between the varying current and the concentration of targets. According to this strategy, a low LOD of $6.3 \times 10^{-14} \mathrm{~mol} / \mathrm{L}$ and a wider detection range of $7.5 \times 10^{-14}-2.0 \times 10^{-10} \mathrm{~mol} / \mathrm{L}$ were obtained by DPV. The sensitivity of this method is higher than other methods for detecting Staphylococcus aureus.

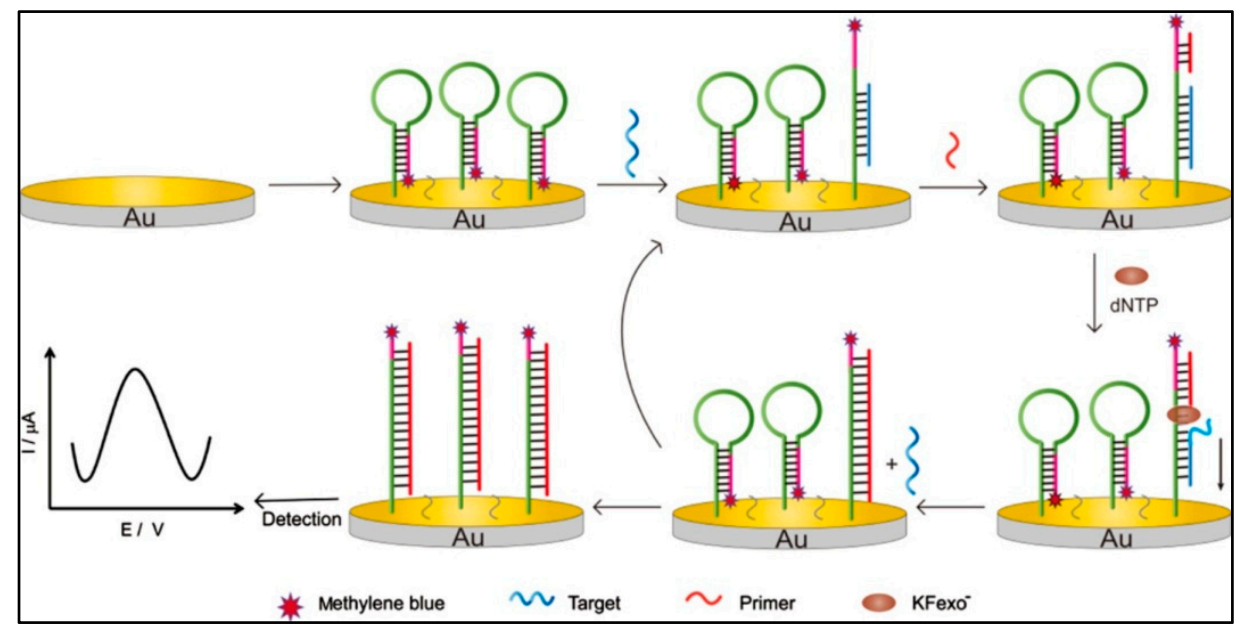

Figure 7. Electrochemical DNA biosensor based on CSRP to detect mecA gene of methicillin-resistant Staphylococcus aureus [146]. Copyright 2015. Reproduced with permission from Elsevier B.V.

Fenglei Gao et al. [147] proposed an electrochemical biosensor to detection DNA hybridization by coupling CSRP with AuNPs catalyzed silver deposition on the biosensor surface. The biosensor possessed an extremely high sensitivity with a LOD of sub-femtomolar level, which attributed to the efficient amplification performance of CSRP. This approach provided a universal platform for ultrasensitive detection of DNA in biomedical and bioanalytical applications.

\section{Catalyzed Hairpin Assembly}

Catalyzed hairpin assembly of DNA (CHA) requires two hairpin DNA probes $\mathrm{H} 1$ and H2. Target DNA can cleave the hairpin structure of $\mathrm{H} 1$, and the opened $\mathrm{H} 1$ probes further unclosed the hairpin structure of $\mathrm{H} 2$ probes. Since $\mathrm{H} 1$ and $\mathrm{H} 2$ have more bases than target DNA, the target DNA is replaced to trigger next displacement. CHA can be carried out without any enzyme, which reduces the detection costs greatly.

Yong Qian et al. [148] constructed a signal-on electrochemical DNA to detect DNA based on target catalyzed hairpin assembly strategy. The principle has been shown in Figure 8. Firstly, the thiolated modified beacon 1 (MB 1) was immobilized on the gold electrode surface by Au-S bonds. In the presence of targets, the hairpin probes were opened and targets hybridized to the MB 1 . Then the ferrocene-labeled molecular beacon 2 (Fc-MB 2) bind with the unhybridized area of MB 1 and extended forward to displace the target DNA. The released targets induced the next amplification. Finally, a number of duplex DNA complexes labeled with $\mathrm{Fc}_{\mathrm{c}}$ were generated. The current was increased dramatically because Fc was confined close to the GE surface for efficient electron transfer. Target 
DNA concentration can be measured by the changes in current intensity. The proposed biosensor has an excellent sensitivity with a LOD of $0.74 \mathrm{fM}$ obtained by DPV. The signal-on biosensor would be applied widely because it is enzyme-free and simple to perform.

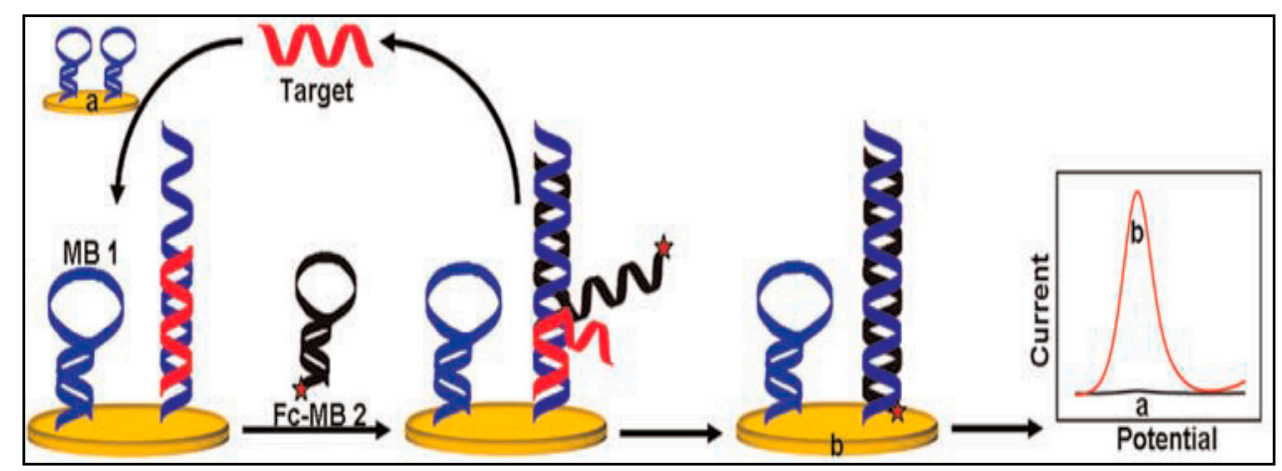

Figure 8. A signal-on electrochemical DNA sensor to detect DNA based on target catalyzed hairpin assembly strategy [148]. Copyright 2014. Reproduced with permission from Elsevier B.V.

Changli Zhong et al. [149] developed an electrochemical biosensor based on hairpin assembly amplification to detect specific DNA with high sensitivity and specificity. $\mathrm{MCH}$ and BSA were used to block the non-specific adsorption sites jointly. The presence of DNA target initiated the hairpin assembly amplification. Eventually, the $\mathrm{H} 1-\mathrm{H} 2$ complex were generated. The $5^{\prime}$ end of biotin-modified $\mathrm{H} 1$ probe hybridized with capture probe immobilized on the GE surface to form capture probe-H1-H2 complex on the electrode surface. The streptavidin-alkaline phosphatase (ST-ALP) bind to biotin and catalyzed the substrate a-naphthol (a-NP) to generate electrochemical signal. Under the optimized conditions, the lower detection limit was found to be $20 \mathrm{pM}$ and the linear range was $25 \mathrm{pM}-25 \mathrm{nM}$.

\subsubsection{Hybridization Chain Reaction}

Hybridization chain reaction (HCR) is an enzyme-free isothermal amplification technique relied on the self-assembly of two DNA hairpins $[150,151]$, which was proposed firstly by Robert M. Dirks et al. in 2004 [152]. In HCR process, the mixture of two DNA hairpins triggers a cascade of hybridization events as the introduction of targets, which generates nicked double helices analogous to alternating copolymers [153]. In recent years, the ingenious combination of HCR and other nucleic acid-based amplification strategies for two-step signal amplification has become a research hotspot in the field of electrochemical biosensors.

Shufeng Liu et al. proposed an isothermal, enzyme-free, and ultrasensitive biosensing strategy to detect DNA by integrated HCR and DNA catalyzed hairpin assembly (CHA) for dual signal amplification [154]. From Figure 9A, we can see a thiolated hairpin DNA probe (immobilized probe) attached to the Au electrode by Au-S bonds firstly. Accompanying the addition of target DNA, it opened the stem-loop structure and hybridized with the hairpin DNA probe. The unhybridized bases of hairpin DNA probe further opened the stem-loop area of capture probe and hybridized with it to displace the target DNA. The released target DNA carried out the successive hybridization and assembly process. After CHA, the nicked double-helix of immobilized probe and capture probe was generated. In the presence of the signal probe and auxiliary probe, HCR was triggered on the electrode surface. Since the signal probe was labeled with $\mathrm{MB}$, as the reaction proceeded, more $\mathrm{MB}$ were immobilized on the electrode surface, which amplified the electrochemical signal largely. By the DPV measuring, the developed biosensor owned a predominant specificity and sensitivity with a LOD of $1.0 \times 10^{-16} \mathrm{~mol} / \mathrm{L}$, which can be applied to other gene-related detections. 

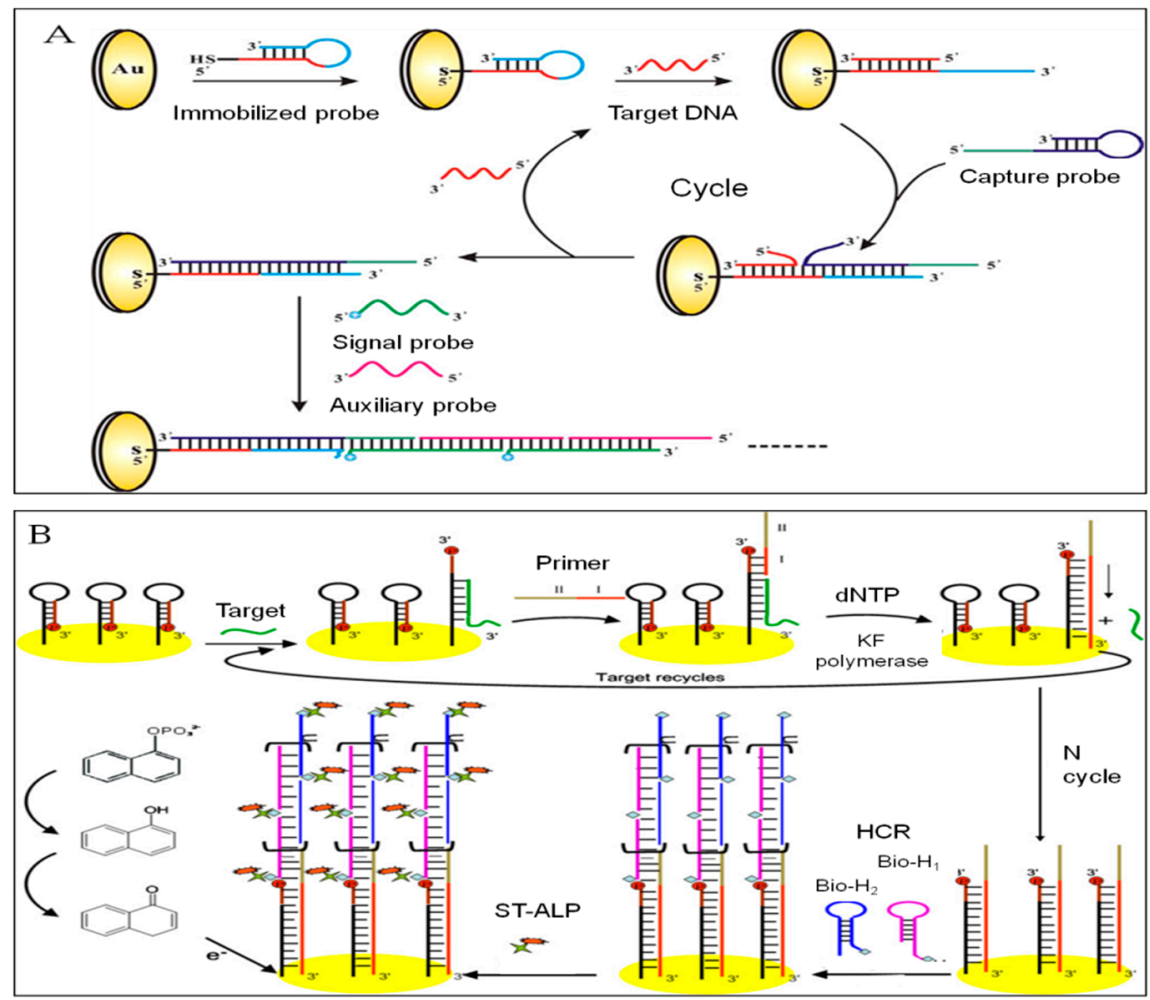

Figure 9. (A) An isothermal, enzyme-free and ultrasensitive design to detect DNA based on HCR and DNA catalyzed hairpin assembly (CHA) [154]. Copyright 2013. Reproduced with permission from Elsevier B.V. (B) An electrochemical DNA biosensor based on HCR and circular strand-displacement polymerase reaction (CSPR) [155]. Copyright 2013. Reproduced with permission from Elsevier B.V.

An electrochemical DNA biosensor coupling HCR to circular strand-replacement polymerization (CSRP) was constructed by Cui Wang et al. [155]. As depicted in Figure 9B, stem-loop capture DNA immobilized on the electrode surface was firstly subjected to CSRP under the induction of target DNA to generate numerous DNA duplex. The capture DNA continued to act as a template to perform HCR to product nicked double-helix. Since the two hairpin DNA involved in the HCR reaction were labeled with biotin, they can combine with streptavidin-alkaline phosphatase (ST-ALP). Then the electrochemical signal was generated by catalyzing the substrate a-naphthol (a-NP). The biosensor based on the dual amplification resulted in a high sensitivity of $8.0 \times 10^{-15} \mathrm{~mol} / \mathrm{L}$ and a wide dynamic range of $10 \mathrm{fM}-1 \mathrm{nM}$.

\subsubsection{DNA Isothermal Amplification Technology}

Rolling Circle Amplification

Rolling circle amplification (RCA) is an enzymatic, isothermal DNA amplification process which utilizes a circular DNA template, a single DNA primer, and Phi29 bacteriophage DNA polymerase to generate a long single-stranded DNA with multiple tandem-repeat sequences [156]. RCA is triggered by the single primer combining on the circular DNA template. The Phi29 bacteriophage DNA polymerase then elongates around the template and eventually accomplishes the circle. The amplification is successive, because the newly product strand continues to displace the previously generated strand thinks to the strand displacement activity of the Phi29 bacteriophage DNA polymerase [157]. Low temperature $\left(30-60{ }^{\circ} \mathrm{C}\right)$ requirement makes this technology attractive for electrochemical DNA biosensors and has been successfully applied to food-borne pathogens detection.

A novel electrochemical DNA biosensor was constructed for Salmonella detection by Dan Zhu et al., which utilized RCA and DNA-AuNPs probe for dual-signal amplification [81]. As can be seen from 
the Figure 10A, probe 1 was firstly immobilized on the electrode surface by Au-S bond. One end of target DNA hybridized with the probe 1 . With the addition of circularization mixture containing probe 2 , the other end hybridized with the probe 2 to form a typical sandwich structure. The presence of dNTPs and phi29 DNA polymerase initiated the RCA to generate micrometer-long ssDNA. Then the detection probe (biotin-DNA-AuNPs) recognized and hybridized with the ssDNA product. The streptavidin-alkaline phosphatase (ST-AP) bind to biotin and catalyzed the substrate a-naphthol (a-NP) to generate enzymatic electrochemical signal. The proposed biosensor has been applied for Salmonella detection in real milk sample with a prominent LOD of $6.76 \times 10^{-18} \mathrm{~mol} / \mathrm{L}$.

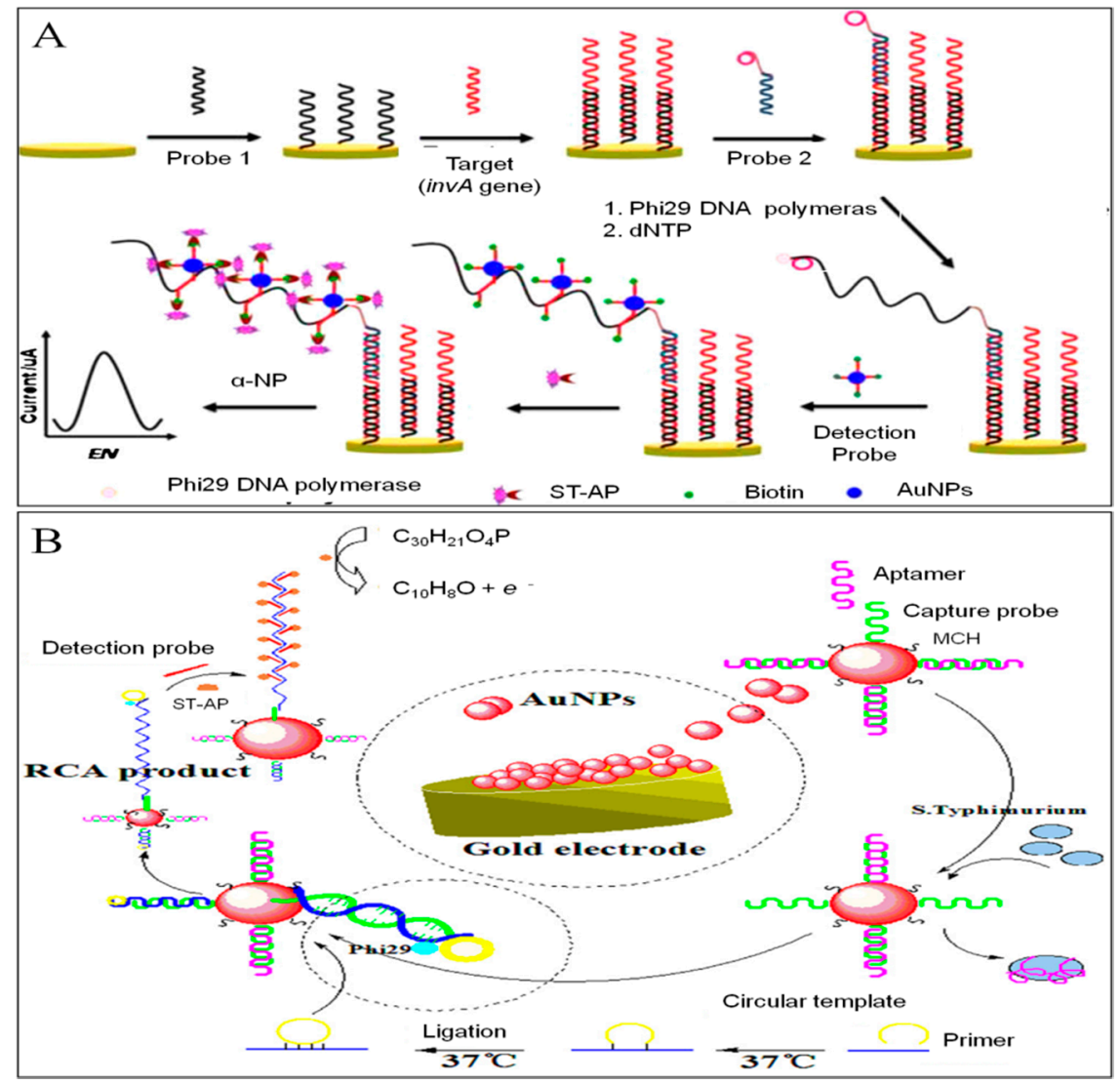

Figure 10. (A) A novel electrochemical sensing strategy based on RCA to detect Salmonella [81]. Copyright 2014. Reproduced with permission from Elsevier B.V. (B) An electrochemical DNA biosensor based on RCA and target-induced aptamer displacement for S. Typhimurium detection [100]. Copyright 2018. Reproduced with permission from Elsevier B.V.

Chuang Ge et al. [100] developed an electrochemical DNA biosensor based on RCA and target-induced aptamer displacement on gold nanoparticles to detect Salmonella typhimurium ultra-sensitively. From Figure 10B, we can see that AuNPs was deposited on the gold electrode to improve the electrode performance. Thiolated capture probe attached to the AuNPs by Au-S bonds. $\mathrm{MCH}$ was used to block non-specific adsorption sites. The sequence of capture probe was complementary hybridized with aptamer. In the presence of $S$. Typhimurium, the specific hybridization between bacteria and aptamer resulted in the release of aptamer from electrode surface. Thereby, RCA primer bind to the capture probe, leading to anchoring numerous circular templates on the electrode surface. In the presence of dNTPs and phi29 DNA polymerase, RCA was initiated to generate micrometer-long ssDNA. Biotinylated detection probe was then hybridized with the multiple tandem-repeat sequences of ssDNA. Streptavidin-alkaline phosphatase (ST-AP), as the label enzyme, combined with biotin to generate enzymatic electrochemical signal by catalyzing enzyme substrate 
$\alpha$-NP. Finally, the sensitivity of electrochemical DNA biosensor was improved dramatically, and an outstanding LOD of $8 \mathrm{CFU} / \mathrm{mL}$ was obtained by DPV.

Loop-Mediated Isothermal Amplification

Loop-mediated isothermal amplification (LAMP) is a mature method of nucleic acid amplification, which was developed by Notomi et al. in 2000 [49]. LAMP performs an auto-cycling strand displacement DNA synthesis under the catalysis of DNA polymerase with high strand displacement activity. At least four primers (two inner and two outer primers) are required for amplification, resulting in a high amplification efficiency of $10^{9}$ copies of target DNA within an hour [122]. LAMP is especially suitable for DNA amplification of pathogens thanks to the ability to amplify a few hundred base-pair long template strands of nucleic acids and the tolerance to various inhibitors present in real food samples [158]. Several electrochemical DNA biosensors based on the high amplification efficiency of LAMP have been reported for determining food-borne pathogens.

An electrochemical DNA biosensor was established by Wei Sun et al. for Yersinia enterocolitica gene sequence detection [122]. Carbon ionic liquid electrode (CILE), as the working electrode, was modified with $\mathrm{V}_{2} \mathrm{O}_{5}$ nanobelts, multi-walled carbon nanotubes (MWCNTs), and chitosan (CTS) to form nanocomposite film. Then sequence-specific ssDNA probes were immobilized on the CILE surface. The LAMP amplicons, as the target DNA, hybridized with ssDNA probe and the hybridization reaction was monitored by the electrochemical indictor methylene blue (MB). Under the optimal conditions, by the DPV measuring, the proposed DNA biosensor showed remarkable stability and sensitivity with a LOD of $1.76 \times 10^{-12} \mathrm{~mol} / \mathrm{L}$ and a linear range of $1.0 \times 10^{-11}-1.0 \times 10^{-6} \mathrm{~mol} / \mathrm{L}$. Minhaz Uddin Ahmed et al. [159] proposed a biosensing strategy to real-time monitor LAMP amplicons of Escherichia coli and Staphylococcus aureus genes by using $\left[\mathrm{Ru}\left(\mathrm{NH}_{3}\right)_{6}\right]^{3+}$ as electrochemical indictor and square wave voltammetry (SWV) as electrochemical technique. The detection can be completed within $30 \mathrm{~min}$, the LOD of $S$. aureus and E. coli is 30 copies/uL and 20 copies/uL, respectively.

\section{Strand Displacement Amplification}

Strand displacement amplification (SDA) was proposed firstly by Walker G. T. in 1992, which based on the a strand-displacing DNA polymerase [160]. Four primers are required that possess bifunction of target recognition and endonucleases target regions. It employs a restriction endonuclease to nick target DNA and an exonuclease-deficient DNA polymerase to displace the downstream DNA strand at the nick sites. Then the displaced strands act as templates to perform an antisense DNA reaction [157]. SDA owns a high amplification efficiency of $10^{8}$ copies of target DNA within two hours. Thus, a large number of studies have applied this strategy to the development of electrochemical DNA biosensors to improve detection sensitivity.

Yuhua Hu et al. [119] designed a electrochemical DNA biosensor to investigate 16S rDNA of Bacillus subtilis, which based on target-induced strand-displacement mechanism and nicking endonuclease signal amplification. (Figure 11A). Firstly, capture probes (CP) were immobilized on the gold electrode by Au-S bonds. Ferrocenecarboxylic acid (FC)-labeled signal probe (SP) was hybridized partly with $\mathrm{CP}$. In the presence of target DNA, target hybridization displaced the nine hybridized bases at the $5^{\prime}$ terminus of SP and released the FC-modified end of SP, allowing FC to approach to the electrode surface and generate current. Then the nicking endonuclease (N.BstNBI) nick the nicking position, leading to the cleavage of $\mathrm{CP}$ and the release of TD. The free TD performed the second cycle of cleavage. After many cycles, remarkable FC current can be detected by the DPV in a low concentration target solution of $8.0 \times 10^{-17} \mathrm{~mol} / \mathrm{L}$. 

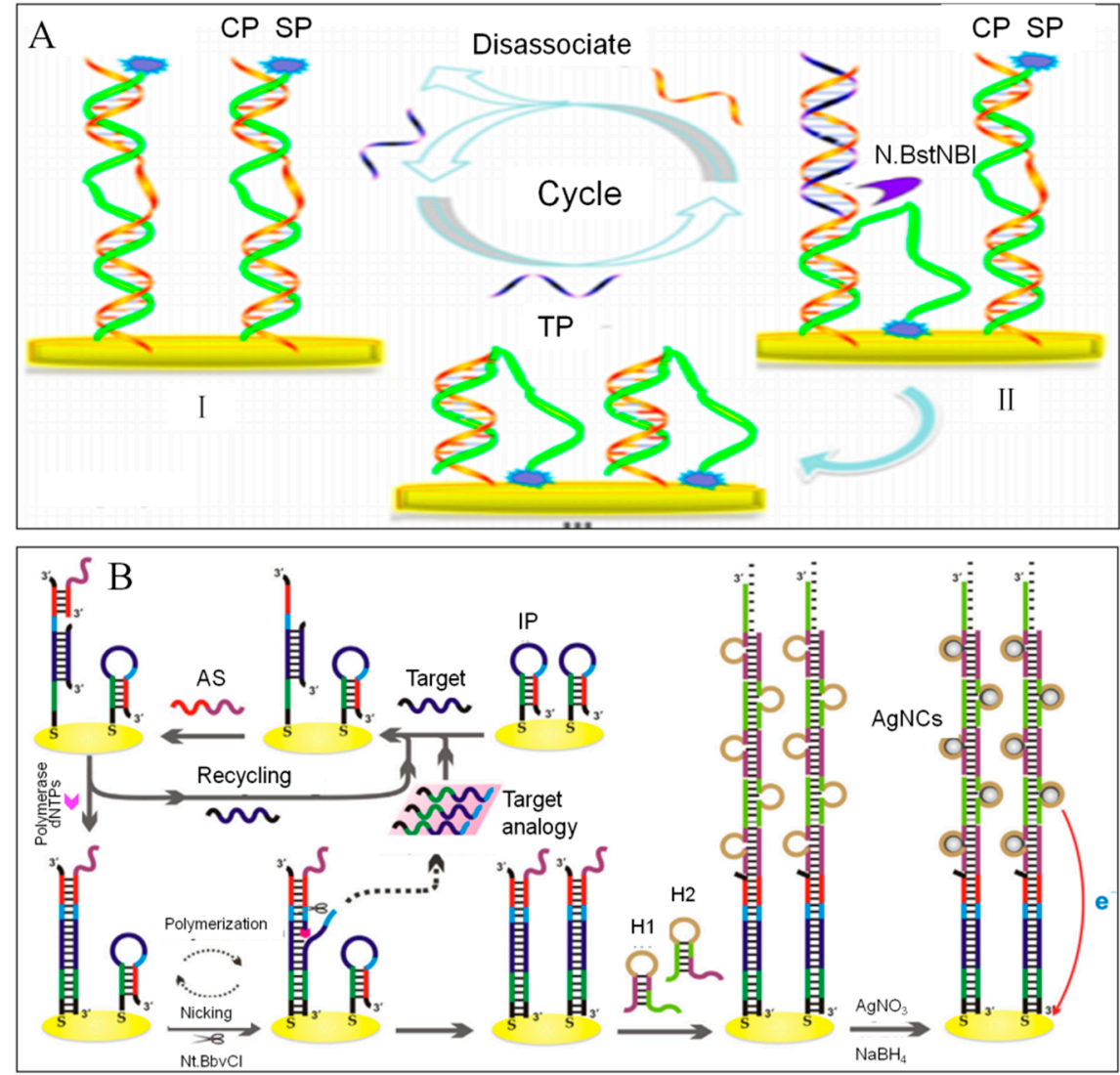

Figure 11. (A) An electrochemical DNA biosensor to investigate 16S rDNA of Bacillus subtilis based on SDA [119,144]. Copyright 2014. Reproduced with permission from American Chemical Society. (B) A label-free and ultrasensitive electrochemical DNA biosensor based on the cascade ASDA and HCR strategy [161]. Copyright 2018. Reproduced with permission from Elsevier B.V.

An label-free and ultrasensitive electrochemical DNA biosensor was proposed by Zhiqiang Chen et al., which integrating autocatalytic strand displacement amplification (ASDA) and hybridization chain reaction (HCR) [161]. Interestingly, ASDA strategy relied on the joint activity of nicking endonuclease (Nt.BbvCI) and Bst DNA polymerase was proposed for the first time. As can be seen from the Figure 11B, the stem-loop probe (IP) was immobilized on the electrode surface by Au-S bonds. In the presence of target, the loop part of IP was opened and hybridized with target. AS probe was designed ingeniously whose $3^{\prime}$ end bind to the stem part of IP. In the presence of Bst DNA polymerase and dNTPs, AS probe extend forward to displace the target. The replaced target initiated the next amplification. Thereafter, multiply dsDNA was product on the electrode surface. Then the nicking endonuclease ( $\mathrm{Nt.BbvCI}$ ) acted on the nicking position ( $3^{\prime}$ end of AS probe), leading to the release of target analogy. Under the action of Bst DNA polymerase, AS probe extend forward to form the duplex DNA structure with $5^{\prime}$ free end of AS probe. $\mathrm{H} 1$ and $\mathrm{H} 2$ probe were used to initiate HCR reaction to form a linear DNA concatamer with cytosine(C)-rich loop region, which can promote the in-situ synthesis of silver nanoclusters (AgNCs) as electrochemical tags for further amplified detection. In the end, with the ASDA and HCR strategies, DNA detection can be achieved with a desired selectivity and an excellent LOD of $0.16 \mathrm{fM}$.

\section{Summary and Conclusions}

Biosensors have become ideal alternative of traditional methods and molecular detection methods for food borne pathogens detection. Especially electrochemical DNA biosensors, due to their merits of low detection limit, wide linear dynamic range, and high reproducibility. In this paper, we overviewed recent advances in the development of electrochemical DNA biosensors that applied to food borne 
pathogens detection. We mainly discussed from the following three aspects: food borne pathogens, electrochemical DNA biosensors and two strategies for improving sensitivity of electrochemical DNA biosensors. In the part of electrochemical DNA biosensor, we highlighted the detection principle of biosensor, main bioreceptors and immobilizing methods on sensing interface, electrochemical techniques, and detection methods. In the long term, more sensitive, specific, cost-efficient, and portable biosensors will be developed to monitor and determine food borne pathogens, thereby further controlling and preventing food borne epidemics.

\section{Future Perspectives}

Although biosensors have created a break-through and became mature increasingly in the field of food borne pathogens detection, there is still a great potential to develop the 'ideal' biosensors. Thus, more efficient and more economical biosensors (offering sensitivity, specificity, and portability) will be the research focuses in the future [86]. According to personal understanding, new advances of biosensors have summarized in Figure 12.

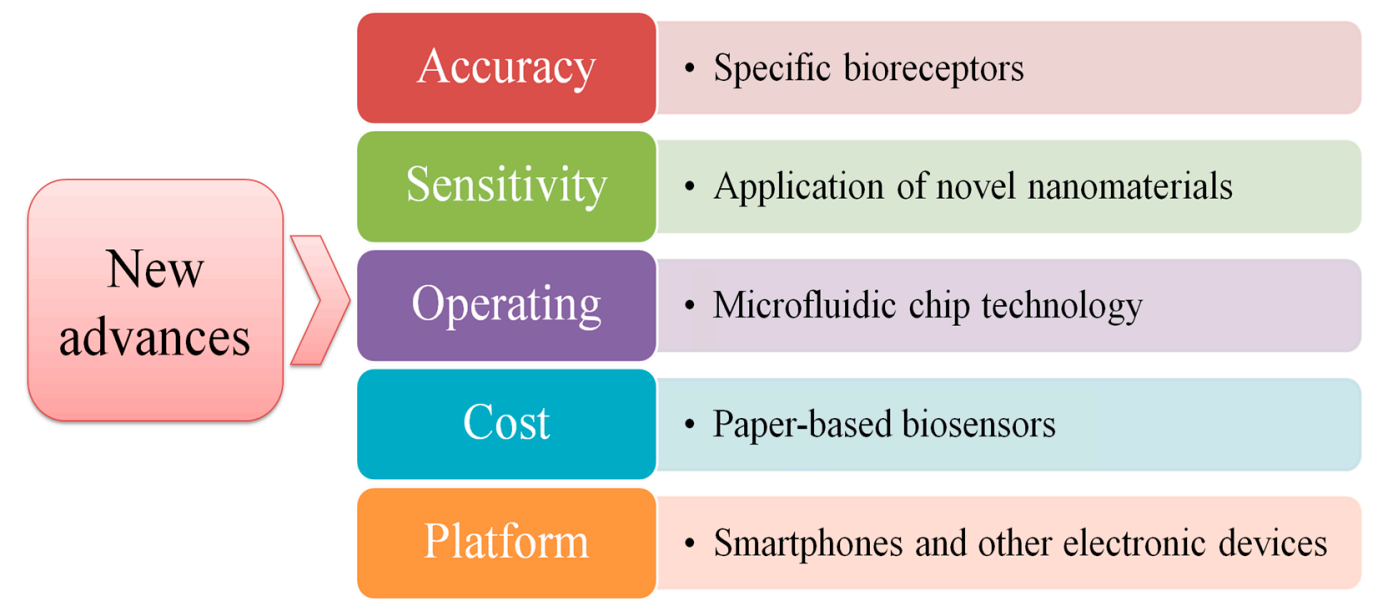

Figure 12. New advances of biosensors.

Accuracy is the most basic requirement for the development of biosensors for food borne pathogens detection. Non-interaction of the bioreceptor with its target should be taken into consideration, because it will affect directly the accuracy of the detection result [162]. Therefore, selecting more specific bioreceptors is one of the future research priorities. For example, aptamer is widely recognized due to its advantages as detailed above. However, it is worth mentioning that the commercial development of aptamers is still in its infancy [86]. Thus, developing new bioreceptors and improving the existing bioreceptors to adapt the commercial needs are future trends.

As the world becomes more concerned about the impact of food borne pathogens on human health, methods with high sensitivity are increasingly in demand to meet the needs of detection. A successful biosensor system should possess the capability to determine the low concentration (less than $10^{2} \mathrm{cfu}$ $\mathrm{mL}^{-1}$ ) of bacterial from the complex food matrix sensitively [47]. Throughout the entire production process of biosensors, electrode modification is of paramount importance to develop biosensors with low detection limits. Thus, in the future, the emergence of novel nanomaterials such as metal-organic frameworks (MOFs) [163-165], nanofiber [166] will open new horizons for improving sensitivity of biosensors by increasing the surface area of electrode and accelerating electron transfer.

Sample preparation, enrichment, and selection are vital steps for food borne pathogens detection [51]. Small sample usage, rapid analysis, and automated detection are ideal standards for the development of biosensors. Microfluidic chip technology was emerging in 1980 and became a research hotpot in miniaturized total analysis systems, which promised a novel pathway to detect DNA. The microfluidic chip has the characteristics of controllable liquid flow, minimal consumption of samples and reagents, and an improvement of analysis speed by factors of hundreds. It can 
perform simultaneous analysis of hundreds of samples in a few minutes or even less. It can realize the pretreatment and analysis of samples online. Therefore, in the future, the integration of microfluidic chip technology and biosensors can become a powerful tool to shorten detection time, achieving automated and high-throughput analysis of samples.

Biosensors offer an unexpected alternative to the traditional and conventional detection methods. Over recent years, enormous efforts have been made to develop biosensing technology in the field of food borne pathogen detection. However, the general cost of detection remains high, hindering its wide-scale application, especially in developing countries. So how to reduce detection costs has always been the most concerning issue for detection's industrialization and commercialization. In order to solve this problem, paper-based biosensors may become an alternative for conventional electrodes due to its merits of low cost, simple product process, and portability. Over the long run, it is expected that future studies should focus on further improving the repeatability and sensitivity of paper-based biosensors by combining them with other signal amplification techniques.

Additionally, even biosensors have been applied widely in the detection field, expensive and large data display platforms for signal output are still required. This deficiency not only increases the cost of detection, but also is not conducive to the development of on-site detection. At present, with the ubiquity of smart-phones, several studies have utilized various mobile devices to output detection signals by developing applications. The smart-phone possesses stupendous development potential owing to its high-quality camera, feasibility, and portability. Additionally, smartphones, as reading tools, do not need any specific dedicated reading device [86]. Mohamed Maarouf Ali Zeinhom et al. designed a novel approach to read the detection result of E. coli O157:H7 in yoghurt and egg by a smartphone based on a field-portable fluorescent imager, which exhibited a low noise to background imaging system [167]. Similarly, Lee et al. proposed a bioassay based on smartphone-integrated dual-wavelength fluorescence to detect biomolecules, which has high accuracy and can obtain clear results [168]. However, few studies have applied smartphones or other mobile devices to electrochemical DNA biosensors, so in the future it may become a research direction for developing miniaturized and portable biosensors.

Acknowledgments: This work was supported by the National Natural Science Foundation of China (no. 31371772).

Conflicts of Interest: The authors declare no conflict of interest regarding this study.

\section{References}

1. Singh, A.; Poshtiban, S.; Evoy, S. Recent advances in bacteriophage based biosensors for food-borne pathogen detection. Sensors 2013, 13, 1763-1786. [CrossRef] [PubMed]

2. Sharma, H.; Agarwal, M.; Goswam, M.; Sharma, A.; Roy, S.; Rai, R.; Murugan, M. Biosensors: Tool for food borne pathogen detection. Vet. World 2013, 6, 968-973. [CrossRef]

3. Wei, C.J.; Zhong, J.L.; Hu, T.; Zhao, X.H. Simultaneous detection of Escherichia coli O157:H7, Staphylococcus aureus and Salmonella by multiplex PCR in milk. 3 Biotech 2018, 8, 76. [CrossRef] [PubMed]

4. Mani-López, E.; García, H.S.; López-Malo, A. Organic acids as antimicrobials to control Salmonella in meat and poultry products. Food Res. Int. 2012, 45, 713-721. [CrossRef]

5. Zhou, K.; Zhong, K.C.; Long, C.; Han, X.F.; Liu, S.L. Development and Validation of a Predictive Model for the Growth of Salmonella enterica in Chicken Meat. J. Food Saf. 2014, 34, 326-332. [CrossRef]

6. Georgescu, N.; Apostol, L.; Gherendi, F. Inactivation of Salmonella enterica serovar Typhimurium on egg surface, by direct and indirect treatments with cold atmospheric plasma. Food Control 2017, 76, 52-61. [CrossRef]

7. Yu, Q.; Zhai, L.G.; Bei, X.M.; Liu, Z.X.; Zhang, C.; Tao, T.T.; Li, J.J.; Lv, F.X.; Zhao, H.Z. Survey of five food-borne pathogens in commercial cold food dishes and their detection by multiplex PCR. Food Control 2015, 59, 862-869. [CrossRef]

8. Bardasi, L.; Taddei, R.; Nocera, L.; Ricchi, M.; Merialdi, G. Shiga Toxin-Producing Escherichia coli in Meat and Vegetable Products in Emilia Romagna Region, Years 2012-2013. Ital. J. Food Saf. 2015, 4, 4511. [CrossRef] [PubMed] 
9. Sofos, J.N.; Geornaras, I. Overview of current meat hygiene and safety risks and summary of recent studies on biofilms, and control of Escherichia coli O157:H7 in nonintact, and Listeria monocytogenes in ready-to-eat, meat products. Meat Sci. 2010, 86, 2-14. [CrossRef] [PubMed]

10. Abadias, M.; Alegre, I.; Oliveira, M.; Altisent, R.; Viñas, I. Growth potential of Escherichia coli O157:H7 on fresh-cut fruits (melon and pineapple) and vegetables (carrot and escarole) stored under different conditions. Food Control 2012, 27,37-44. [CrossRef]

11. Gullianklanian, M.; Sánchezsolis, J.M. Growth kinetics of Escherichia coli O157:H7 on the epicarp of fresh vegetables and fruits. Braz. J. Microbiol. 2018, 49, 104-111. [CrossRef] [PubMed]

12. Baloch, A.B.; Yang, H.; Feng, Y.; Xi, M.; Wu, Q.; Tang, J.; He, X.; Xiao, Y.; Xia, X. Presence and Antimicrobial Resistance of Escherichia coli in Ready-to-Eat Foods in Shaanxi, China. J. Food Prot. 2017, 80, 420-424. [CrossRef] [PubMed]

13. Zhang, S.; Wu, Q.; Zhang, J.; Zhu, X. Occurrence and Characterization of Enteropathogenic Escherichia coli (EPEC) in Retail Ready-to-Eat Foods in China. Foodborne Pathog. Dis. 2015, 13, 49-55. [CrossRef] [PubMed]

14. Halabi, M.; Orth, D.; Grif, K.; Wiesholzer-pittl, M.; Kainz, M.; Schöberl, J.; Dierich, M.P.; Allerberger, F.; Würzner, R. Prevalence of Shiga toxin-, intimin- and haemolysin genes in Escherichia coli isolates from drinking water supplies in a rural area of Austria. Int. J. Hyg. Environ. Health 2008, 211, 454-457. [CrossRef] [PubMed]

15. Chen, J.H.; Alcaine, S.; Jiang, Z.W.; M Rotello, V.; R Nugen, S. Detection of Escherichia coli in Drinking Water Using T7 Bacteriophage-Conjugated Magnetic Probe. Anal. Chem. 2015, 87, 8977-8984. [CrossRef] [PubMed]

16. Perera, M.N.; Abuladze, T.; Li, M.R.; Woolston, J.; Sulakvelidze, A. Bacteriophage cocktail significantly reduces or eliminates Listeria monocytogenes contamination on lettuce, apples, cheese, smoked salmon and frozen foods. Food Microbiol. 2015, 52, 42-48. [CrossRef] [PubMed]

17. Mclennon, J.; Borza, A.; Eisebraun, M.; Garduño, R.A. Improved Recovery of Stressed Listeria monocytogenes from Frozen Foods. Food Anal. Methods 2018, 11, 403-414. [CrossRef]

18. Mengesha, D.; Zewde, B.M.; Toquin, M.T.; Kleer, J.; Hildebrant, G.; Gebreves, W.A. Occurrence and distribution of Listeria monocytogenes and other Listeria species in ready-to-eat and raw meat products. Berliner Und Münchener Tierärztliche Wochenschrift 2009, 122, 20-24. [PubMed]

19. Rodriguez-Lazaro, D.; Gonzalez-García, P.; Valero, A.; Hernandez, M. Application of the SureTect Detection Methods for Listeria monocytogenes and Listeria spp. in Meat, Dairy, Fish, and Vegetable Products. Food Anal. Methods 2015, 8, 1-6. [CrossRef]

20. Nastou, A.; Jonathan, R.; Smirniotis, P.; Makri, L.; Kontominas, M.; Likotrafiti, E. Efficacy of household washing treatments for the control of Listeria monocytogenes on salad vegetables. Int. J. Food Microbiol. 2012, 159, 247-253. [CrossRef] [PubMed]

21. Muhammed, W.; Muleta, D.; Deneke, Y.; Gashaw, A.; Bitew, M. Studies on occurence of Listeria monocytogenes and other species in milk and milk products in retail market of Jimma town, Ethiopia. Asian J. Dairy Food Res. 2013, 32, 35-39.

22. Salazar, J.K.; Bathija, V.M.; Carstens, C.K.; Narula, S.S.; Shazer, A.; Stewart, D.; Tortotello, M.L. Listeria monocytogenes Growth Kinetics in Milkshakes Made from Naturally and Artificially Contaminated Ice Cream. Front. Microbiol. 2018, 9, 62. [CrossRef] [PubMed]

23. Wernars, K.; Heuvelman, C.J.; Chakraborty, T.; Notermans, S.H.W. Use of the polymerase chain reaction for direct detection of Listeria monocytogenes in soft cheese. J. Appl. Microbiol. 2010, 70, 121-126.

24. Zhang, Z.H.; Liu, W.T.; Xu, H.Y.; Aguilar, Z.P.; Shah, N.P.; Wei, H. Propidium monoazide combined with real-time PCR for selective detection of viable Staphylococcus aureus in milk powder and meat products. J. Dairy Sci. 2015, 98, 1625-1633. [CrossRef] [PubMed]

25. Cho, J.I.; Joo, I.S.; Choi, J.H.; Jung, K.H.; Choi, E.J.; Son, N.R.; Han, M.K.; Jeong, S.J.; Lee, S.H.; Hwang, I.G. Distribution of Methicillin-resistant Staphylococcus aureus (MRSA) in RAW Meat and Fish Samples in Korea. Food Sci. Biotechnol. 2014, 23, 999-1003. [CrossRef]

26. Can, H.Y.; Elmal1, M.; Karagöz, A. Molecular Typing and Antimicrobial Susceptibility of Staphylococcus aureus Strains Isolated from Raw Milk, Cheese, Minced Meat, and Chicken Meat Samples. Korean J. Food Sci. Anim. Resour. 2017, 37, 175-180. [CrossRef] [PubMed]

27. Zhang, P.P.; Li, M.Y.; Zhao, G.M.; Cui, W.M.; Gao, X.P.; Liu, Y.X.; Zhao, L.J.; Wang, Y.F. Thermal Inactivation Properties of Shigella in Smoked Cooked Ham. Food Sci. 2017, 38, 40-45. 
28. Shin, W.S.; Hong, W.S.; Lee, K.E. Assessment of Microbiological Quality for Raw Materials and Cooked Foods in Elementary School Food Establishment. J. Korean Soc. Food Sci. Nutr. 2008, 37, 379-389. [CrossRef]

29. Shahin, K.; Bouzari, M. Bacteriophage application for biocontrolling Shigella flexneri in contaminated foods. J. Food Sci. Technol. 2018, 55, 550-559. [CrossRef] [PubMed]

30. Sonbol, H.; Joseph, S.; McAuley, C.M.; Craven, H.M.; Forsythe, S.J. Multilocus sequence typing of Cronobacter spp. from powdered infant formula and milk powder production factories. Int. Dairy J. 2013, 30, 1-7. [CrossRef]

31. Pinapérez, M.C.; Rodrigo, D.; Martínez, A. Non-Thermal Inactivation of Cronobacter Sakazakii in Infant Formula Milk: A Review. Crit. Rev. Food Sci. Nutr. 2015, 56, 1620-1629. [CrossRef] [PubMed]

32. Fu, S.Z.; Gao, J.X.; Liu, Y.; Chen, H.Y. Isolation of Cronobacter spp. isolates from infant formulas and their survival in the production process of infant formula. Czech J. Food Sci. 2011, 29, 391-399. [CrossRef]

33. Forsythe, S.J. Enterobacter sakazakii and other bacteria in powdered infant milk formula. Matern. Child Nutr. 2010, 1, 44-50. [CrossRef] [PubMed]

34. Azwai, S.M.; Alfallani, E.A.; Abolqhait, S.K.; Garbaj, A.M.; Naas, H.T.; Moawad, A.A.; Gammoudi, F.T.; Rayes, H.M.; Barbieri, I.; Eldaghayes, I.M. Isolation and molecular identification of Vibrio spp. by sequencing of 16S rDNA from seafood, meat and meat products in Libya. Open Vet. J. 2016, 6, 36-43. [CrossRef] [PubMed]

35. Dileep, V.; Sanath, K.; Yadhu, K.; Mitsuaki, N.; Indrani, K.; Iddya, K. Application of polymerase chain reaction for detection of Vibrio parahaemolyticus associated with tropical seafoods and coastal environment. Lett. Appl. Microbiol. 2010, 36, 423-427. [CrossRef] [PubMed]

36. Kim, Y.W.; Lee, S.H.; Hwang, I.G.; Yoon, K.S. Effect of Temperature on Growth of Vibrio paraphemolyticus and Vibrio vulnificus in Flounder, Salmon Sashimi and Oyster Meat. Int. J. Environ. Res. Public Health 2012, 9, 4662-4675. [CrossRef] [PubMed]

37. Wang, Y.; Zhang, S.Y.; Yu, J.Y.; Zhang, H.; Yuan, Z.Q.; Sun, Y.S.; Zhang, L.; Zhu, Y.F.; Song, H.B. An outbreak of Proteus mirabilis food poisoning associated with eating stewed pork balls in brown sauce, Beijing. Food Control 2010, 21, 302-305. [CrossRef]

38. Adedeji, B.S.; Ezeokoli, O.T.; Ezekiel, C.N.; Obadina, A.O.; Somorin, Y.M.; Sulyok, M.; Adeleke, R.A.; Warth, B.; Nwangburuka, C.C.; Omemu, A.M.; et al. Bacterial species and mycotoxin contamination associated with locust bean, melon and their fermented products in south-western Nigeria. Int. J. Food Microbiol. 2017, 258, 73-80. [CrossRef] [PubMed]

39. Tompkin, R.B.; Christiansen, L.N.; Shaparis, A.B. Enhancing nitrite inhibition of Clostridium botulinum with isoascorbate in perishable canned cured meat. Appl. Environ. Microbiol. 1978, 35, 59. [PubMed]

40. Roberts, T.A.; Gibson, A.M.; Robinson, A. Factors controlling the growth of Clostridium botulinum types A and B in pasteurized, cured meats. Int. J. Food Sci. Technol. 2010, 17, 307-326. [CrossRef]

41. Hospital, X.F.; Hierro, E.; Stringer, S.; Fernández, M. A study on the toxigenesis by Clostridium botulinum in nitrate and nitrite-reduced dry fermented sausages. Int. J. Food Microbiol. 2015, 218, 66-70. [CrossRef] [PubMed]

42. Delbrassinne, L.; Andjelkovic, M.; Dierick, K.; Denayer, S.; Mahillon, J.; Loco, J.V. Prevalence and levels of Bacillus cereus emetic toxin in rice dishes randomly collected from restaurants and comparison with the levels measured in a recent foodborne outbreak. Foodborne Pathog. Dis. 2012, 9, 809-814. [CrossRef] [PubMed]

43. Martinelli, D.; Fortunato, F.; Tafuri, S.; Cozza, V.; Chironna, M.; Germinario, C.; Pedalino, B.; Prato, R. Lessons learnt from a birthday party: A Bacillus cereus outbreak, Bari, Italy, January 2012. Ann. Ist. Super. Sanita 2013, 49, 391-394. [PubMed]

44. Delbrassinne, L.; Botteldoorn, N.; Andjelkovic, M.; Dierick, K.; Denayer, S. An emetic Bacillus cereus outbreak in a kindergarten: Detection and quantification of critical levels of cereulide toxin. Foodborne Pathog. Dis. 2015, 12, 84. [CrossRef] [PubMed]

45. Sallam, K.I. Prevalence of Campylobacter in chicken and chicken by-products retailed in Sapporo area, Hokkaido, Japan. Food Control 2007, 18, 1113-1120. [CrossRef]

46. Whyte, R.; Hudson, J.A.; Graham, C. Campylobacter in chicken livers and their destruction by pan frying. Lett. Appl. Microbiol. 2010, 43, 591-595. [CrossRef] [PubMed]

47. Muniandy, S.; The, S.J.; Thong, K.L.; Thiha, A.; Dinshaw, I.J.; Lai, C.W.; Ibrahim, F.; Leo, B.F. Carbon Nanomaterial-Based Electrochemical Biosensors for Foodborne Bacterial Detection. Crit. Rev. Anal. Chem. 2019, 49, 510-533. [CrossRef] [PubMed] 
48. Mullis, K.B.; Ferré, F.; Gibbs, R.A. The Polymerase Chain Reaction. Infect. Dis. News. 1994, 8, 36-39.

49. Notomi, T.; Okayama, H.; Masubuchi, H.; Yonekawa, T.; Watanabe, K.; Amino, N.; Hase, T. Loop-mediated isothermal amplification of DNA. Nucleic Acids Res. 2000, 28, E63. [CrossRef] [PubMed]

50. Schweitzer, B.; Roberts, S.; Grimwade, B.; Shao, W.P.; Wang, M.J.; Fu, Q.; Shu, Q.P.; Laroche, I.; Zhou, Z.M.; Tchernev, V.T.; et al. Multiplexed protein profiling on microarrays by rolling-circle amplification. Nat. Biotechnol. 2002, 20, 359-365. [CrossRef] [PubMed]

51. Silva, N.F.D.; Magalhãesb, J.M.C.S.; Freirec, C.; Delerue-Matosa, C. Electrochemical biosensors for Salmonella: State of the art and challenges in food safety assessment. Biosens. Bioelectron. 2018, 99, 667-682. [CrossRef] [PubMed]

52. Reta, N.; Saint, C.P.; Michelmore, A.; Prieto-Simon, B.; Voelcker, N.H. Nanostructured Electrochemical Biosensors for Label-Free Detection of Water- and Food-Borne Pathogens. ACS Appl. Mater. Interfaces 2018, 10, 6055-6072. [CrossRef] [PubMed]

53. Arora, P.; Sindhu, A.; Dilbaghi, N.; Chaudhury, A. Biosensors as innovative tools for the detection of food borne pathogens. Biosens. Bioelectron. 2011, 28, 1-12. [CrossRef] [PubMed]

54. Rafique, B.; Iqbal, M.; Mehmood, T.; Shaheen, M.A. Electrochemical DNA biosensors: A review. Sens. Rev. 2019, 39, 34-50. [CrossRef]

55. Liu, S.; Zheng, Z.; Li, X. Advances in pesticide biosensors: Current status, challenges, and future perspectives. Anal. Bioanal. Chem. 2013, 405, 63-90. [CrossRef] [PubMed]

56. Cohen, N.D.; Martin, L.J.; Simpson, R.B.; Wallis, D.E. Comparison of polymerase chain reaction and microbiological culture for detection of salmonellae in equine feces and environmental samples. Am. J. Vet. Res. 1996, 57, 780. [PubMed]

57. Ngwa, G.A.; Schop, R.; Weir, S.; León-Velarde, C.G.; Odumeru, J.A. Detection and enumeration of E. coli O157:H7 in water samples by culture and molecular methods. J. Microbiol. Methods 2013, 92, 164-172. [CrossRef] [PubMed]

58. Poli, M.A.; Rivera, V.R.; Neal, D. Sensitive and specific colorimetric ELISAs for Staphylococcus aureus enterotoxins A and B in urine and buffer. Toxicon 2002, 40, 1723-1726. [CrossRef]

59. Chunglok, W.; Wuragil, D.K.; Oaewc, S.; Somasundrumc, M.; Surareungchai, W. Immunoassay based on carbon nanotubes-enhanced ELISA for Salmonella enterica serovar Typhimurium. Biosens. Bioelectron. 2011, 26, 3584-3589. [CrossRef] [PubMed]

60. Liu, H.L.; Chen, X.Z.; Li, K.S.; Du, H.F.; Chen, Y.T.; Lian, X.W.; Lu, X.P.; Yuan, M.; Ye, W.H. Extraction and identification of E. coli O157:H7 lipopolysaccharide and development of an indirect ELISA. Chin. J. Zoonoses 2011, 27, 637-640.

61. Zhu, F.; Rogelj, S.; Kieft, T.L. Rapid detection of Escherichia coli O157:H7 by immunomagnetic separation and real-time PCR. Int. J. Food Microbiol. 2011, 99, 47-57.

62. Chen, Z.Z.; Cai, L.; Chen, M.Y.; Lin, Y.; Pang, D.W.; Tang, H.W. Indirect immunofluorescence detection of $E$. coli O157:H7 with fluorescent silica nanoparticles. Biosens. Bioelectron. 2015, 66, 95-102. [CrossRef] [PubMed]

63. Jin, M.; Lang, J.; Shen, Z.Q.; Chen, Z.L. A Rapid Subtractive Immunization Method to Prepare Discriminatory Monoclonal Antibodies for Food E. coli O157:H7 Contamination. PLoS ONE 2012, 7, e31352. [CrossRef] [PubMed]

64. Tavakoli, H.R.; Najafi, A.; Ahmadi, A. Rapid, specific and concurrent detection of Listeria, Salmonella and Escherichia coli pathogens by multiplex PCR in Iranian food. Afr. J. Microbiol. Res. 2010, 4, 2503-2507.

65. Malorny, B.; Bunge, C.; Helmuth, R. A real-time PCR for the detection of Salmonella Enteritidis in poultry meat and consumption eggs. J. Microbiol. Methods 2007, 70, 245-251. [CrossRef] [PubMed]

66. Kim, J.H.; Rhim, S.R.; Kim, K.T.; Paik, H.D.; Lee, J.Y. Simultaneous Detection of Listeria monocytogenes, Escherichia coli O157:H7, Bacillus cereus, Salmonella spp., and Staphylococcus aureus in Low-fatted Milk by Multiplex PCR. Korean J. Food Sci. Anim. Resour. 2014, 34, 717-723. [CrossRef] [PubMed]

67. Arunrut, N.; Kiatpathomchai, W.; Ananchaipattana, C. Multiplex PCR assay and lyophilization for detection of Salmonella spp., Staphylococcus aureus and Bacillus cereus in pork products. Food Sci. Biotechnol. 2018, 27, 867-875. [CrossRef] [PubMed]

68. Lee, N.; Kwon, K.Y.; Oh, S.K.; Chang, H. A multiplex PCR assay for simultaneous detection of Escherichia coli O157:H7, Bacillus cereus, Vibrio parahaemolyticus, Salmonella spp., Listeria monocytogenes, and Staphylococcus aureus in Korean ready-to-eat food. Foodborne Pathog. Dis. 2014, 11, 574-580. [CrossRef] [PubMed] 
69. Yu, S.; Yan, L.N.; Wu, X.; Li, F.; Wang, D.; Xu, H.Y. Multiplex PCR coupled with propidium monoazide for the detection of viable Cronobacter sakazakii, Bacillus cereus, and Salmonella spp. in milk and milk products. J. Dairy Sci. 2017, 100, 7874. [CrossRef] [PubMed]

70. Hu, L.J.; Ma, L.M.; Zheng, S.M.; He, X.H.; Hammack, T.S.; Brown, E.W.; Zhang, G.D. Development of a novel loop-mediated isothermal amplification (LAMP) assay for the detection of Salmonella ser. Enteritidis from egg products. Food Control 2018, 88, 190-197. [CrossRef]

71. Kordas, A.; Papadakis, G.; Milioni, D.; Champ, J.; Descroix, S.; Gizeli, E. Rapid Salmonella detection using an acoustic wave device combined with the RCA isothermal DNA amplification method. Sens. Bio-Sens. Res. 2016, 11, 121-127. [CrossRef]

72. Âsterberg, F.W.; Rizzi, G.; Donolato, M.; Bejhed, R.S.; Mezger, A.; Strömberg, M.; Nilsson, M.; Strømme, M.; Svedlindh, P.; Hansen, M.; et al. On-chip detection of rolling circle amplified DNA molecules from Bacillus globigii spores and Vibrio cholerae. Small 2014, 10, 2877-2882. [CrossRef] [PubMed]

73. Wang, Z.; Yang, Q.; Zhang, Y.Z.; Meng, Z.X.; Ma, X.Y.; Zhang, W. Saltatory Rolling Circle Amplification (SRCA): A Novel Nucleic Acid Isothermal Amplification Technique Applied for Rapid Detection of Shigella spp. in Vegetable Salad. Food Anal. Methods 2018, 11, 504-513. [CrossRef]

74. Shukla, S.; Haldoraia, Y.; Bajpaia, V.K.; Rengarajc, A.; Hwangc, S.K.; Song, X.J.; Kimd, M.; Huhc, Y.S.; Hana, Y.K. Electrochemical coupled immunosensing platform based on graphene oxide/gold nanocomposite for sensitive detection of Cronobacter sakazakii in powdered infant formula. Biosens. Bioelectron. 2018, 109, 139. [CrossRef] [PubMed]

75. Rao, D.R.; Reddy, B.M.; Sunki, G.R.; Pulusani, S.R. Influence of antimicrobial compound(s) extracted from milk fermented by Streptococcus thermophilus on keeping quality of meat and milk. J. Food Qual. 2010, 4, 247-258. [CrossRef]

76. Izadi, Z.; Sheikh-Zeinoddin, M.; Ensafi, A.A.; Soleimanian-Zad, S. Fabrication of an electrochemical DNA-based biosensor for Bacillus cereus detection in milk and infant formula. Biosens. Bioelectron. 2016, 80, 582-589. [CrossRef] [PubMed]

77. Eivazzadeh-Keihan, R.; Pashazadeh-Panahi, P.; Baradaran, B.; Guardia, M.D.L.; Hejazi, M.; Sohrabi, H.; Mokhtarzadeh, A.; Maleki, A. Recent progress in optical and electrochemical biosensors for sensing of Clostridium botulinum neurotoxin. TrAC Trends Anal. Chem. 2018, 103, 184-197. [CrossRef]

78. Holowko, M.B.; Poh, C.L. Designing and Assembling Plasmids for the Construction of Escherichia coli Biosensor for Vibrio cholerae Detection. Methods Mol. Biol. 2018, 1772, 445. [PubMed]

79. Abdalhai, M.H.; Fernandes, A.M.; Xia, X.; Musa, A.; Ji, J.; Sun, X. Electrochemical Genosensor to Detect Pathogenic Bacteria (Escherichia coli O157:H7) As Applied in Real Food Samples (Fresh Beef) To Improve Food Safety and Quality Control. J. Agric. Food Chem. 2015, 63, 5017-5025. [CrossRef] [PubMed]

80. Nazari-Vanani, R.; Sattarahmady, N.; Yadegari, H.; Heli, H. A novel and ultrasensitive electrochemical DNA biosensor based on an ice crystals-like gold nanostructure for the detection of Enterococcus faecalis gene sequence. Colloids Surf. B Biointerfaces 2018, 166, 245-253. [CrossRef] [PubMed]

81. Zhu, D.; Yan, Y.R.; Lei, P.H.; Shen, B.; Cheng, W.; Ju, H.X.; Ding, S.J. A novel electrochemical sensing strategy for rapid and ultrasensitive detection of Salmonella by rolling circle amplification and DNA-AuNPs probe. Anal. Chim. Acta 2014, 846, 44-50. [CrossRef] [PubMed]

82. Benvidi, A.; Tezerjani, M.D.; Jahanbani, S.; Ardakani, M.M.; Moshtaghioun, S.M. Comparison of impedimetric detection of DNA hybridization on the various biosensors based on modified glassy carbon electrodes with PANHS and nanomaterials of RGO and MWCNTs. Talanta 2016, 147, 621-627. [CrossRef] [PubMed]

83. Low, K.F.; Chuenrangsikul, K.; Rijiravanich, P.; Suraneungchai, W.; Chan, Y.Y. Electrochemical genosensor for specific detection of the food-borne pathogen, Vibrio cholerae. World J. Microbiol. Biotechnol. 2012, 28, 1699-1706. [CrossRef] [PubMed]

84. Hassani, S.; Akmalc, M.R.; Salek-Maghsoudib, A.; Rahmania, S.; Ganjalic, M.R.; Norouzic, P.; Abdollahia, M. Novel label-free electrochemical aptasensor for determination of Diazinon using gold nanoparticles-modified screen-printed gold electrode. Biosens. Bioelectron. 2018, 120, 122-128. [CrossRef] [PubMed]

85. Sun, W.; Qi, X.W.; Zhang, Y.Y.; Yang, H.R.; Gao, H.W.; Chen, Y.; Sun, Z.F. Electrochemical DNA biosensor for the detection of Listeria monocytogenes with dendritic nanogold and electrochemical reduced graphene modified carbon ionic liquid electrode. Electrochim. Acta 2012, 85, 145-151. [CrossRef]

86. Gaudin, V. Advances in biosensor development for the screening of antibiotic residues in food products of animal origin-A comprehensive review. Biosens. Bioelectron. 2017, 90, 363-377. [CrossRef] [PubMed] 
87. Tombelli, S.; Minunni, M.; Mascini, M. Analytical applications of aptamers. Biosens. Bioelectron. 2005, 20, 2424-2434. [CrossRef] [PubMed]

88. Lönne, M.; Zhu, G.H.; Stahl, F.; Walter, J.G. Aptamer-Modified Nanoparticles as Biosensors. Adv. Biochem. Eng. Biotechnol. 2014, 140, 121-154. [PubMed]

89. Bini, A.; Centi, S.; Tombelli, S.; Minunni, M. Development of an optical RNA-based aptasensor for C-reactive protein. Anal. Bioanal. Chem. 2008, 390, 1077-1086. [CrossRef] [PubMed]

90. Ma, X.; Jiang, Y.H.; Jia, F.; Yu, Y.; Chen, J.; Wang, Z.P. An aptamer-based electrochemical biosensor for the detection of Salmonella. J. Microbiol Methods 2014, 98, 94-98. [CrossRef] [PubMed]

91. Zhou, L.; Ou, L.J.; Chu, X.; Shen, G.L. An electrochemical aptasensor based on gold nanoparticles dotted graphene modified glassy carbon electrode for label-free detection of bisphenol A in milk samples. Food Chem. 2014, 162, 34-40. [CrossRef] [PubMed]

92. Wu, W.; Fang, Z.Y.; Zhao, S.M.; Lu, X.W. A simple aptamer biosensor for Salmonellae enteritidis based on fluorescence-switch signaling graphene oxide. RSC Adv. 2014, 4, 22009-22012. [CrossRef]

93. Lee, H.; Kim, B.C.; Kim, K.W.; Kim, Y.K.; Kim, J.B.; Oh, M.K. A sensitive method to detect Escherichia coli based on immunomagnetic separation and real-time PCR amplification of aptamers. Biosens. Bioelectron. 2009, 24, 3550-3555. [CrossRef] [PubMed]

94. Ozalp, V.C.; Bayramoglu, G.; Kavruk, M.; Keskin, B.B.; Oktem, H.A.; Arica, M.Y. Pathogen detection by core-shell type aptamer-magnetic preconcentration coupled to real-time PCR. Anal. Biochem. 2014, 447, 119-125. [CrossRef] [PubMed]

95. Xie, S.B.; Chai, Y.Q.; Yuan, Y.L.; Bai, L.J.; Yuan, R. Development of an electrochemical method for Ochratoxin A detection based on aptamer and loop-mediated isothermal amplification. Biosens. Bioelectron. 2014, 55, 324-329. [CrossRef] [PubMed]

96. Lin, M.Y.; Chang, Y.W.; Tai, Y.T.; Yang, Y.S. High sensitive, colorimetric, isothermal nucleic acids amplification: A versatile platform for protein biosensors. In Proceedings of the International Conference on Sensing Technology, Tainan, Taiwan, 30 November-3 December 2008.

97. Yang, L.L.; Zhang, Y.; Li, R.B.; Lin, C.Y.; Guo, L.H.; Qiu, B.; Lin, Z.Y.; Chen, G.N. Electrochemiluminescence biosensor for ultrasensitive determination of ochratoxin A in corn samples based on aptamer and hyperbranched rolling circle amplification. Biosens. Bioelectron. 2015, 70, 268-274. [CrossRef] [PubMed]

98. Zhou, L.; Ou, L.J.; Chu, X.; Shen, G.L. Aptamer-Based Rolling Circle Amplification: A Platform for Electrochemical Detection of Protein. Anal. Chem. 2007, 79, 7492-7500. [CrossRef] [PubMed]

99. Yan, M.M.; Bai, W.H.; Zhu, C.; Huang, Y.F.; Yan, Y.J.; Chen, A.L. Design of nuclease-based target recycling signal amplification in aptasensors. Biosens. Bioelectron. 2016, 77, 613-623. [CrossRef] [PubMed]

100. Ge, C.; Yuan, R.; Yi, L.; Yang, J.L.; Zhang, H.W.; Lia, L.X.; Nian, W.Q.; Yi, G. Target-induced aptamer displacement on gold nanoparticles and rolling circle amplification for ultrasensitive live Salmonella typhimurium electrochemical biosensing. J. Electroanal. Chem. 2018, 826, 174-180. [CrossRef]

101. Rashid, J.I.A.; Yusof, N.A. The strategies of DNA immobilization and hybridization detection mechanism in the construction of electrochemical DNA sensor: A review. Sens. Bio-Sens. Res. 2017, 16, 19-31. [CrossRef]

102. Velusamy, V.; Arshak, K.; Yang, C.F.; Yu, L.; Korostynska, O.; Adley, C. Comparison between DNA Immobilization Techniques on a Redox Polymer Matrix. Am. J. Anal. Chem. 2011, 2, 392-400. [CrossRef]

103. Amouzadeh Tabrizi, M.; Shamsipur, M. A label-free electrochemical DNA biosensor based on covalent immobilization of salmonella DNA sequences on the nanoporous glassy carbon electrode. Biosens. Bioelectron. 2015, 69, 100-105. [CrossRef] [PubMed]

104. Sheikhzadeh, E.; Chamsaz, M.; Turner, A.P.F.; Jager, E.W.H.; Beni, V. Label-free impedimetric biosensor for Salmonella Typhimurium detection based on poly [pyrrole-co-3-carboxyl-pyrrole] copolymer supported aptamer. Biosens. Bioelectron. 2016, 80, 194-200. [CrossRef] [PubMed]

105. Arora, K.; Prabhakar, N.; Chand, S.; Malhotra, B.D. Immobilization of single stranded DNA probe onto polypyrrole-polyvinyl sulfonate for application to DNA hybridization biosensor. Sens. Actuators B Chem. 2007, 126, 655-663. [CrossRef]

106. Arora, K.; Prabhakar, N.; Chand, S.; Malhotra, B.D. Escherichia coli Genosensor Based on Polyaniline. Anal. Chem. 2007, 79, 6152-6158. [CrossRef] [PubMed]

107. Jia, F.; Duan, N.; Wu, S.J.; Ma, X.Y.; Xia, Y.; Wang, Z.P.; Wei, X.L. Impedimetric aptasensor for Staphylococcus aureus based on nanocomposite prepared from reduced graphene oxide and gold nanoparticles. Microchim. Acta 2014, 181, 967-974. [CrossRef] 
108. Reich, P.; Stoltenburg, R.; Strehlitz, B.; Frense, D.; Beckmann, D. Development of an Impedimetric Aptasensor for the Detection of Staphylococcus aureus. Int. J. Mol. Sci. 2017, 18, 2484. [CrossRef] [PubMed]

109. Andrade, C.; Nascimento, J.M.; Oliveira, I.S.; De Oliveira, C.V.J. Nanostructured sensor based on carbon nanotubes and clavanin A for bacterial detection. Colloids Surf. B Biointerfaces 2015, 135, 833-839. [CrossRef] [PubMed]

110. de Miranda, J.L.; Oliveira, M.D.L.; Oliveira, I.S.; Frias, I.A.M.; Franco, O.L.; Andrade, C.A.S. A simple nanostructured biosensor based on clavanin A antimicrobial peptide for gram-negative bacteria detection. Biochem. Eng. J. 2017, 124, 108-114. [CrossRef]

111. Singh, A.; Sinsinbar, G.; Choudhary, M.; Kumar, V.; Pasricha, R.; Verma, H.N.; Singh, S.P.; Arora, K. Graphene oxide-chitosan nanocomposite based electrochemical DNA biosensor for detection of typhoid. Sens. Actuators B Chem. 2013, 185, 675-684. [CrossRef]

112. Tiwari, I.; Singh, M.; Pandey, C.M.; Sumana, G. Electrochemical genosensor based on graphene oxide modified iron oxide-chitosan hybrid nanocomposite for pathogen detection. Sens. Actuators B Chem. 2015, 206, 276-283. [CrossRef]

113. Mazzaracchio, V.; Neagu, D.; Porchetta, A.; Marcoccio, E.; Pomponi, A.; Faggioni, G.; D’Amore, N.; Notargiacomo, A.; Pea, M.; Moscone, D.; et al. A label-free impedimetric aptasensor for the detection of Bacillus anthracis spore simulant. Biosens. Bioelectron. 2019, 126, 640-646. [CrossRef] [PubMed]

114. Ligaj, M.; Tichoniuk, M.; Gwiazdowska, D.; Filipiak, M. Electrochemical DNA biosensor for the detection of pathogenic bacteria Aeromonas hydrophila. Electrochim. Acta 2014, 128, 67-74. [CrossRef]

115. Vanegas, D.C.; Rong, Y.; Schwalb, N.; Hills, K.D.; Gomes, C.; McLamore, E.S. Rapid detection of listeria spp. using an internalin A aptasensor based on carbon-metal nanohybrid structures. In Proceedings of the SPIE Sensing Technology + Applications, Baltimore, MD, USA, 13 May 2015; Volume 9487, p. 948708.

116. Singh, A.; Choudhary, M.; Singh, M.P.; Verma, H.N.; Singh, S.P.; Arora, K. DNA Functionalized Direct Electro-deposited Gold nanoaggregates for Efficient Detection of Salmonella typhi. Bioelectrochemistry 2015, 105, 7-15. [CrossRef] [PubMed]

117. Luo, C.H.; Tang, H.; Cheng, W.; Yan, Y.; Zhang, D.C.; Ju, H.X.; Ding, S.J. A sensitive electrochemical DNA biosensor for specific detection of Enterobacteriaceae bacteria by Exonuclease III-assisted signal amplification. Biosens. Bioelectron. 2013, 48, 132-137. [CrossRef] [PubMed]

118. Li, X.L.; Fu, H.; He, Y.; Zhai, Q.; Guo, J.; Qing, K.Q.; Yi, G. Electrochemical Aptasensor for Rapid and Sensitive Determination of Salmonella Based on Target-Induced Strand Displacement and Gold Nanoparticle Amplification. Anal. Lett. 2016, 49, 2405-2417. [CrossRef]

119. Hu, Y.H.; Xu, X.Q.; Liu, Q.H.; Wang, L.; Lin, Z.Y.; Chen, G.N. Ultrasensitive electrochemical biosensor for detection of DNA from Bacillus subtilis by coupling target-induced strand displacement and nicking endonuclease signal amplification. Anal. Chem. 2014, 86, 8785-8790. [CrossRef] [PubMed]

120. Jia, F.; Duan, N.; Wu, S.J.; Dai, R.T.; Wang, Z.P.; Li, X.M. Impedimetric Salmonella aptasensor using a glassy carbon electrode modified with an electrodeposited composite consisting of reduced graphene oxide and carbon nanotubes. Microchim. Acta 2016, 183, 337-344. [CrossRef]

121. Hasan, M.R.; Pulingam, T.; Appaturi, J.N.; Zifruddin, A.N.; Teh, S.J.; Lim, T.W.; Ibrahim, F.; Leo, B.F.; Thong, K.L. Carbon nanotube-based aptasensor for sensitive electrochemical detection of whole-cell Salmonella. Anal. Biochem. 2018, 554, 34-43. [CrossRef] [PubMed]

122. Sun, W.; Qin, P.; Gao, H.W.; Li, G.C.; Jiao, K. Electrochemical DNA biosensor based on chitosan/nano-V2O5/MWCNTs composite film modified carbon ionic liquid electrode and its application to the LAMP product of Yersinia enterocolitica gene sequence. Biosens. Bioelectron. 2010, 25, 1264-1270. [CrossRef] [PubMed]

123. Pei, Q.Q.; Wang, Y.; Liu, S.; Qin, Y.F.; Leng, X.Q.; Cui, X.J.; Huang, J.D. Exonuclease III-aided autonomous cascade signal amplification: A facile and universal DNA biosensing platform for ultrasensitive electrochemical detection of S. typhimurium. New J. Chem. 2017, 41, 7613-7620. [CrossRef]

124. Bai, Y.H.; Li, J.Y.; Xu, J.J.; Chen, H.Y. Ultrasensitive electrochemical detection of DNA hybridization using $\mathrm{Au} / \mathrm{Fe}_{3} \mathrm{O}_{4}$ magnetic composites combined with silver enhancement. Analyst 2010, 135, 1672-1679. [CrossRef] [PubMed]

125. Wang, H.S.; Ju, H.X.; Chen, H.Y. Voltammetric Behavior and Detection of DNA at Electrochemically Pretreated Glassy Carbon Electrode. Electroanalysis 2015, 13, 1105-1109. [CrossRef] 
126. Thorp and, H.H. Cutting out the middleman: DNA biosensors based on electrochemical oxidation. Trends Biotechnol. 1998, 16, 117-121. [CrossRef]

127. Armistead, P.M.; Thorp, H.H. Electrochemical Detection of Gene Expression in Tumor Samples: Overexpression of Rak Nuclear Tyrosine Kinase. Bioconjug. Chem. 2002, 13, 172-176. [CrossRef] [PubMed]

128. Azimzadeh, M.; Rahaie, M.; Nasirizadeh, N.; Ashtari, K.; Naderi-Manesh, H. An electrochemical nanobiosensor for plasma miRNA-155, based on graphene oxide and gold nanorod, for early detection of breast cancer. Biosens. Bioelectron. 2016, 77, 99-106. [CrossRef] [PubMed]

129. Huang, H.Y.; Bai, W.Q.; Dong, C.X.; Guo, R.; Liu, Z.H. An ultrasensitive electrochemical DNA biosensor based on graphene/Au nanorod/polythionine for human papillomavirus DNA detection. Biosens. Bioelectron. 2015, 68, 442-446. [CrossRef] [PubMed]

130. Ye, Y.K.; Yan, W.W.; Liu, Y.Q.; He, S.D.; Cao, X.D.; Xu, X.; Zheng, H.S.; Gunasekaran, S. Electrochemical detection of Salmonella using an invA genosensor on polypyrrole-reduced graphene oxide modified glassy carbon electrode and AuNPs-horseradish peroxidase-streptavidin as nanotag. Anal. Chim. Acta 2019, 1074, 80-88. [CrossRef] [PubMed]

131. Hajihosseini, S.; Nasirizadeh, N.; Hejazi, M.S.; Yaghmaei, P. A sensitive DNA biosensor fabricated from gold nanoparticles and graphene oxide on a glassy carbon electrode. Mater. Sci. Eng. C 2016, 61, 506-515. [CrossRef] [PubMed]

132. Gholivand, M.B.; Akbari, A. A sensitive electrochemical genosensor for highly specific detection of thalassemia gene. Biosens. Bioelectron. 2019, 129, 182-188. [CrossRef] [PubMed]

133. Shi, A.Q.; Wang, J.; Han, X.W.; Fang, X.; Zhang, Y.Z. A sensitive electrochemical DNA biosensor based on gold nanomaterial and graphene amplified signal. Sens. Actuators B Chem. 2014, 200, 206-212. [CrossRef]

134. Muniandy, S.; Teh, S.J.; Appaturi, J.N.; Thong, K.L.; Lai, C.W.; Ibrahim, F.; Leo, B.F. A reduced graphene oxide-titanium dioxide nanocomposite based electrochemical aptasensor for rapid and sensitive detection of Salmonella enterica. Bioelectrochemistry 2019, 127, 136-144. [CrossRef] [PubMed]

135. Benvidi, A.; Firouzabadi, A.D.; Moshtaghiun, S.M.; Mazloum-Ardakani, M.; Tezerjani, M.D. Ultrasensitive DNA sensor based on gold nanoparticles/reduced graphene oxide/glassy carbon electrode. Anal. Biochem. 2015, 484, 24-30. [CrossRef] [PubMed]

136. Kim, Y.S.; Raston, N.H.A.; Gu, M.B. Aptamer-based nanobiosensors. Biosens. Bioelectron. 2016, 76, 2-19. [PubMed]

137. Wei, B.; Mao, K.; Liu, N.; Zhang, M.; Yang, Z.G. Graphene nanocomposites modified electrochemical aptamer sensor for rapid and highly sensitive detection of prostate specific antigen. Biosens. Bioelectron. 2018, 121, 41-46. [CrossRef] [PubMed]

138. Iijima, S. Helical microtubules of graphitic carbon. Nature 1991, 354, 56-58. [CrossRef]

139. Lan, L.Y.; Yao, Y.; Ping, J.F.; Ying, Y.B. Recent advances in nanomaterial-based biosensors for antibiotics detection. Biosens. Bioelectron. 2017, 91, 504-514. [CrossRef] [PubMed]

140. Jafari, S.; Faridbod, F.; Norouzi, P.; Dezfuli, A.S.; Ajloo, D. Fatemeh Mohammadipanah, Mohammad Reza Ganjali. Detection of Aeromonas hydrophila DNA oligonucleotide Sequence using a Biosensor Design based on Ceria Nanoparticles Decorated Reduced Graphene Oxide and Fast Fourier Transform Square Wave Voltammetry. Anal. Chim. Acta 2015, 895, 80-88. [CrossRef] [PubMed]

141. Sun, Y.; He, X.X.; Ji, J.; Jia, M.; Wang, Z.P.; Sun, X.L. A highly selective and sensitive electrochemical CS-MWCNTs/Au-NPs composite DNA biosensor for Staphylococcus aureus gene sequence detection. Talanta 2015, 141, 300-306. [CrossRef] [PubMed]

142. Ye, Y.K.; Liu, Y.Q.; He, S.D.; Xu, X.; Cao, X.D.; Ye, Y.W.; Zheng, H.S. Ultrasensitive electrochemical DNA sensor for virulence invA gene of Salmonella using silver nanoclusters as signal probe. Sens. Actuators $B$ Chem. 2018, 272, 53-59. [CrossRef]

143. Sun, W.; Wang, X.L.; Lu, Y.X.; Gong, S.X.; Qi, X.W.; Lei, B.X.; Sun, Z.F.; Li, G.J. Electrochemical deoxyribonucleic acid biosensor based on electrodeposited graphene and nickel oxide nanoparticle modified electrode for the detection of salmonella enteritidis gene sequence. Mater. Sci. Eng. C 2015, 49, 34-39. [CrossRef] [PubMed]

144. Li, Y.; Deng, J.; Fang, L.C.; Yu, K.K.; Huang, H.; Jiang, L.L.; Liang, W.B.; Zheng, J.S. A novel electrochemical DNA biosensor based on HRP-mimicking hemin/G-quadruplex wrapped GOx nanocomposites as tag for detection of Escherichia coli O157:H7. Biosens. Bioelectron. 2015, 63, 1. [CrossRef] [PubMed] 
145. Qi, X.W.; Gao, H.W.; Zhang, Y.Y.; Wang, X.Z.; Chen, Y.; Sun, W. Electrochemical DNA biosensor with chitosan- $\mathrm{Co}(3) \mathrm{O}(4)$ nanorod-graphene composite for the sensitive detection of Staphylococcus aureus nuc gene sequence. Bioelectrochemistry 2012, 88, 42-47. [CrossRef] [PubMed]

146. Wang, T.; Zhang, Z.; Li, Y.Y.; Xie, G.M. Amplified electrochemical detection of mecA gene in methicillin-resistant Staphylococcus aureus based on target recycling amplification and isothermal strand-displacement polymerization reaction. Sens. Actuators B Chem. 2015, 221, 148-154. [CrossRef]

147. Gao, F.L.; Zhu, Z.; Lei, J.P.; Geng, Y.; Ju, H.X. Sub-femtomolar electrochemical detection of DNA using surface circular strand-replacement polymerization and gold nanoparticle catalyzed silver deposition for signal amplification. Biosens. Bioelectron. 2013, 39, 199-203. [CrossRef] [PubMed]

148. Qian, Y.; Tang, D.Q.; Du, L.L.; Zhang, Y.Z.; Zhang, L.X.; Gao, F.L. A novel signal-on electrochemical DNA sensor based on target catalyzed hairpin assembly strategy. Biosens. Bioelectron. 2015, 64, 177-181. [CrossRef] [PubMed]

149. Santos, C.S.; Lima, A.S.; Battistel, D.; Daniele, S.; Bertotti, M. Fabrication and Use of Dual-function Iridium Oxide Coated Gold SECM Tips. An Application to $\mathrm{pH}$ Monitoring above a Copper Electrode Surface during Nitrate Reduction. Electroanalysis 2016, 28, 1441-1447. [CrossRef]

150. Choi, H.M.T.; Beck, V.A.; Pierce, N.A. Next-Generation in Situ Hybridization Chain Reaction: Higher Gain, Lower Cost, Greater Durability. ACS Nano 2014, 8, 4284-4294. [CrossRef] [PubMed]

151. Dong, J.; Cui, X.; Deng, Y.; Tang, Z. Amplified detection of nucleic acid by G-quadruplex based hybridization chain reaction. Biosens. Bioelectron. 2012, 38, 258-263. [CrossRef] [PubMed]

152. Dirks, R.M.; Pierce, N.A. Triggered amplification by hybridization chain reaction. Proc. Natl. Acad. Sci. USA 2004, 101, 15275-15278. [CrossRef] [PubMed]

153. Evanko, D. Hybridization chain reaction. Nat. Methods 2004, 1, 186-187. [CrossRef]

154. Liu, S.F.; Wang, Y.; Ming, J.J.; Lin, Y.; Cheng, C.B.; Li, F. Enzyme-free and ultrasensitive electrochemical detection of nucleic acids by target catalyzed hairpin assembly followed with hybridization chain reaction. Biosens. Bioelectron. 2013, 49, 472-477. [CrossRef] [PubMed]

155. Wang, C.; Zhou, H.; Zhu, W.P.; Li, H.B.; Jiang, J.H.; Shen, G.L.; Yu, R.Q. Ultrasensitive electrochemical DNA detection based on dual amplification of circular strand-displacement polymerase reaction and hybridization chain reaction. Biosens. Bioelectron. 2013, 47, 324-328. [CrossRef] [PubMed]

156. Mayboroda, O.; Katakis, I.; O'Sullivan, C.K. Multiplexed isothermal nucleic acid amplification. Anal. Biochem 2018, 545, 20-30. [CrossRef] [PubMed]

157. Li, J.; Macdonald, J. Advances in isothermal amplification: Novel strategies inspired by biological processes. Biosens. Bioelectron. 2015, 64, 196-211. [CrossRef] [PubMed]

158. Giuffrida, M.C.; Spoto, G. Integration of isothermal amplification methods in microfluidic devices: Recent advances. Biosens. Bioelectron. 2017, 90, 174-186. [CrossRef] [PubMed]

159. Ahmed, M.U.; Nahar, S.; Safavieh, M.; Zourob, M. Real-time electrochemical detection of pathogen DNA using electrostatic interaction of a redox probe. Analyst 2013, 138, 907-915. [CrossRef] [PubMed]

160. Walker, G.T.; Nadeau, J.G.; Spears, P.A.; Schram, J.L.; Nycz, C.M.; Shank, D.D. Multiplex strand displacement amplification (SDA) and detection of DNA sequences from Mycobacterium tuberculosis and other mycobacteria. Nucleic Acids Res. 1994, 22, 2670-2677. [CrossRef] [PubMed]

161. Chen, Z.Q.; Liu, Y.; Xin, C.; Zhao, J.K.; Liu, S.F. A cascade autocatalytic strand displacement amplification and hybridization chain reaction event for label-free and ultrasensitive electrochemical nucleic acid biosensing. Biosens. Bioelectron. 2018, 113, 1-8. [CrossRef] [PubMed]

162. Rubab, M.; Shahbaz, H.M.; Olaimat, A.N.; Oh, D.H. Biosensors for rapid and sensitive detection of Staphylococcus aureus in food. Biosens. Bioelectron. 2018, 105, 49-57. [CrossRef] [PubMed]

163. Bhardwaj, N.; Bhardwaj, S.K.; Mehta, J.; Kim, K.H.; Deep, A. MOF-Bacteriophage Biosensor for Highly Sensitive and Specific Detection of Staphylococcus aureus. ACS Appl. Mater. Interfaces 2017, 9, 33589-33598. [CrossRef] [PubMed]

164. Zhao, H.Q.; Qiu, G.H.; Liang, Z.; Li, M.M.; Sun, B.; Qin, L.; Yang, S.P.; Chen, W.H.; Chen, J.X. A zinc(II)-based two-dimensional MOF for sensitive and selective sensing of HIV-1 ds-DNA sequences. Anal. Chim. Acta 2016, 922, 55-63. [CrossRef] [PubMed]

165. Yu, H.; Han, J.; An, S.J.; Xie, G.; Chen, S.P. Ce(III, IV)-MOF electrocatalyst as signal-amplifying tag for sensitive electrochemical aptasensing. Biosens. Bioelectron. 2018, 109, 63-69. [CrossRef] [PubMed] 
166. Rezaei, B.; Ghani, M.; Shoushtari, A.M.; Rabiee, M. Electrochemical biosensors based on nanofibres for cardiac biomarker detection: A comprehensive review. Biosens. Bioelectron. 2016, 78, 513-523. [CrossRef] [PubMed]

167. Zeinhom, M.M.A.; Wang, Y.J.; Song, Y.; Zhu, M.J.; Lin, Y.H.; Du, D. A portable smart-phone device for rapid and sensitive detection of E. coli O157:H7 in Yoghurt and Egg. Biosens. Bioelectron. 2018, 99, 479-485. [CrossRef] [PubMed]

168. Lee, W.I.; Shrivastava, S.; Duy, L.T.; Kim, B.Y.; Son, Y.M.; Lee, N.E. A smartphone imaging-based label-free and dual-wavelength fluorescent biosensor with high sensitivity and accuracy. Biosens. Bioelectron. 2017, 94, 643-650. [CrossRef] [PubMed]

(C) 2019 by the authors. Licensee MDPI, Basel, Switzerland. This article is an open access article distributed under the terms and conditions of the Creative Commons Attribution (CC BY) license (http://creativecommons.org/licenses/by/4.0/). 